\title{
Article
}

\section{Qualifying Land Use and Land Cover Dynamics and Their Impacts on Ecosystem Service in Central Himalaya Transboundary Landscape Based on Google Earth Engine}

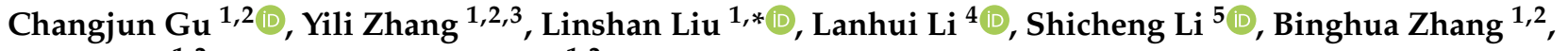 \\ Bohao Cui ${ }^{1,2}$ and Mohan Kumar Rai ${ }^{1,2}$ \\ 1 Key Laboratory of Land Surface Pattern and Simulation, \\ Institute of Geographic Sciences and Natural Resources Research, CAS, Beijing 100101, China; \\ gucj.18b@igsnrr.ac.cn (C.G.); zhangyl@igsnrr.ac.cn (Y.Z.); zhangbh.17b@igsnrr.ac.cn (B.Z.); \\ cuibh.19b@igsnrr.ac.cn (B.C.); mkrai2019@igsnrr.ac.cn (M.K.R.) \\ 2 College of Resources and Environment, University of Chinese Academy of Sciences, Beijing 100049, China \\ CAS Center for Excellence in Tibetan Plateau Earth Sciences, Beijing 100101, China \\ 4 Fujian Key Laboratory of Pattern Recognition and Image Understanding, Xiamen University of Technology, \\ Xiamen 361024, China; lilh.15b@igsnrr.ac.cn \\ 5 Department of Land Resource Management, School of Public Administration, China University of Geosciences, \\ Wuhan 430074, China; lisc@cug.edu.cn \\ * Correspondence: liuls@igsnrr.ac.cn
}

Citation: Gu, C.; Zhang, Y.; Liu, L.; Li, L.; Li, S.; Zhang, B.; Cui, B.; Rai, M.K. Qualifying Land Use and Land Cover Dynamics and Their Impacts on Ecosystem Service in Central Himalaya Transboundary Landscape Based on Google Earth Engine. Land 2021, 10, 173. https://doi.org/ 10.3390/land10020173

Academic Editor: Claudia Capitani Received: 28 December 2020

Accepted: 2 February 2021

Published: 8 February 2021

Publisher's Note: MDPI stays neutral with regard to jurisdictional claims in published maps and institutional affiliations.

Copyright: () 2021 by the authors. Licensee MDPI, Basel, Switzerland. This article is an open access article distributed under the terms and conditions of the Creative Commons Attribution (CC BY) license (https:// creativecommons.org/licenses/by/ $4.0 /)$.

\begin{abstract}
Land use and land cover (LULC) changes are regarded as one of the key drivers of ecosystem services degradation, especially in mountain regions where they may provide various ecosystem services to local livelihoods and surrounding areas. Additionally, ecosystems and habitats extend across political boundaries, causing more difficulties for ecosystem conservation. LULC in the Kailash Sacred Landscape (KSL) has undergone obvious changes over the past four decades; however, the spatiotemporal changes of the LULC across the whole of the KSL are still unclear, as well as the effects of LULC changes on ecosystem service values (ESVs). Thus, in this study we analyzed LULC changes across the whole of the KSL between 2000 and 2015 using Google Earth Engine (GEE) and quantified their impacts on ESVs. The greatest loss in LULC was found in forest cover, which decreased from $5443.20 \mathrm{~km}^{2}$ in 2000 to $5003.37 \mathrm{~km}^{2}$ in 2015 and which mainly occurred in KSL-Nepal. Meanwhile, the largest growth was observed in grassland (increased by $548.46 \mathrm{~km}^{2}$ ), followed by cropland (increased by $346.90 \mathrm{~km}^{2}$ ), both of which mainly occurred in KSL-Nepal. Further analysis showed that the expansions of cropland were the major drivers of the forest cover change in the KSL. Furthermore, the conversion of cropland to shrub land indicated that farmland abandonment existed in the KSL during the study period. The observed forest degradation directly influenced the ESV changes in the KSL. The total ESVs in the KSL decreased from $36.53 \times 10^{8} \mathrm{USD}^{-1}$ in 2000 to $35.35 \times 10^{8}$ USD y $^{-1}$ in 2015 . Meanwhile, the ESVs of the forestry areas decreased by $1.34 \times 10^{8} \mathrm{USD}^{-1}$. This shows that the decrease of ESVs in forestry was the primary cause to the loss of total ESVs and also of the high elasticity. Our findings show that even small changes to the LULC, especially in forestry areas, are noteworthy as they could induce a strong ESV response.
\end{abstract}

Keywords: land use and land cover; ecosystem service value; Google Earth Engine (GEE); forest fragmentation; transboundary landscape; Himalaya

\section{Introduction}

Ecosystem services can be defined as the benefits that humans gain from ecological processes that contribute to human well-being [1-4]. However, global ecosystem services have been altered by human activities over the past few centuries [5]. Anthropogenic activities can be found in almost every corner of the globe after the onset of the Anthropocene and have emerged as a global driver rapidly sculpturing the ecosystem [6-8]. 
According to Costanza et al. [9], 60\% of worldwide ecosystem services have degraded over the past several decades. Land use and land cover (LULC) changes, mainly driven by human activities [10], are considered to be one of the greatest and most immediate threats affecting ecosystem services [11,12]. LULC changes have thus been considered an important research topic with regard to global environmental change and sustainable development [13-16]. Mountain ecosystems are rich sources of biodiversity [17] and host high plant endemism [18]. They also provide diverse ecosystem services [19]. On the other hand, mountain regions are fragile areas that are sensitive to external forces [20]. Human-driven LULC changes are considered to be among the greatest ecological pressures in mountain regions [21].

As a typical mountain system, the Hindu Kush Himalayan (HKH) region extends ca. four million square kilometers, encompassing eight countries: Afghanistan, Bangladesh, Bhutan (all), China, India, Myanmar, Nepal (all), and Pakistan [22,23]. It is the source of ten major river systems, which provide water, ecosystem services, and the basis for livelihoods to a population of around 210.53 million people in the region [24]. Harboring four of 36 global biodiversity hotspots [25], it provides habitats for numerous wild species but is deeply threatened. The region is extremely fragile in terms of land cover diversity and its association with variable terrain, climate, and sociodemographic interactions. The HKH region is significantly rich in terms of biodiversity but is also one of the least studied in the world [26,27]. The fourth and fifth reports of the Intergovernmental Panel on Climate Change (IPCC) explicitly pointed to the HKH as a data deficient area [28,29].

Even though 39\% of the HKH region's land is divided into protected areas to support better conservation [30], the effectiveness of protected areas still faces challenges [31,32]. Almost one-third of the protected areas are transboundary and in these areas, as elsewhere in the HKH region, ecosystems and habitats extend across political boundaries [23]. When conservation policies meet with the administrative and political borders in the territory, the situation becomes more complex because of the nonconformity between natural ecological boundaries and administrative borders [33]. This means that landscape-level planning is necessary and management requires regional cooperation if the ecosystems or habitats are transboundary in nature [34]. For better conservation, seven transboundary landscapes have been identified across the HKH region-based on biodiversity significance, representation of ecoregions, cultural significance, and contiguity of ecosystems for conservation and sustainable development of the region [35] — and are being used to develop transboundary landscape-level planning and management approaches.

The Kailash Sacred Landscape (KSL) is one of the seven transboundary landscapes, named after the Mount Kailash, which is seen as the holiest shrine for several religions [36]. Three of Asia's great rivers have their sources in the landscape: the Indus, the Brahmaputra, and the Ganges River, which provide essential transboundary ecosystem goods and services, both locally and downstream [37]. However, increasingly frequent human activities, together with climate change, have caused rapid land use and land cover changes over the past decades. Uddin et al. [23] have shown the forest fragmentation in Nepal's Kailash Sacred Landscape from 1990 to 2009 and further predicted the future LULC in 2030. Duan et al. [38] assessed LULC changes in the Kailash Sacred Landscape of China from 1990-2008 and quantified driving forces. Singh et al. [39] studied the LULC changes in the Kailash Sacred Landscape of China from 1976-2011 and also pointed out forest fragmentation in the Indian part. All of these studies assessed the LULC changes in three countries using different data sources, study periods, classification systems, and methods. It is almost impossible to compare the differences in LULC changes among the three countries. In short, LULC data covering the entire area are still unclear.

A detailed and accurate knowledge of land cover is crucial for many scientific and operational applications and, as such, it has been identified as an Essential Climate Variable [40]. The development of remote sensing provided an important tool to explore historical and current land cover information at the local, national, regional, and global levels [41]. The complicated process of processing satellite imagery and the high cost of 
computing power has limited the relevant research. Google Earth Engine (GEE) provides a high-performance cloud-based platform and access for any researcher [42,43]. GEE houses a massive imagery data collection, including Landsat, MODIS (Moderate Resolution Imaging Spectroradiometer), and Sentinel that can be directly accessed using the JavaScript code within minutes, allowing users to interactively test and develop algorithms and preview results in real time without downloading any images [44]. Furthermore, GEE offers a packaged algorithm for image preprocessing and machine learning classifiers. The efficiency of GEE has been demonstrated by recent studies, including with regard to vegetation change detection [45,46], urban area mapping [47,48], agricultural land mapping [49], grassland monitoring [50,51], extraction of water bodies [52,53], and disaster monitoring [54].

Hence, we used satellite images and GEE to assess LULC changes and examine their impacts on ecosystem service values (ESVs) in the KSL between 2000 and 2015. Our main objectives were to explore: (1) the dynamics of LULC between 2000 and 2015; (2) the ESV changes based on LULC; and (3) their implications for landscape conservation and sustainable land use. This study is expected to provide insights into sacred landscape conservation for future land management.

\section{Materials and Methods}

\subsection{Study Area}

The Kailash Sacred Landscape is located between $79^{\circ} 40^{\prime} \mathrm{E}-82^{\circ} 30^{\prime} \mathrm{E}$ and $29^{\circ} 10^{\prime} \mathrm{N}-$ $31^{\circ} 20^{\prime} \mathrm{N}$ (Figure 1). Mount Kailash, which is considered by multiple religions as the center of the universe, and Lake Manasarovar are the most prominent features in the KSL. There are two sacred lakes near Mount Kailash, Lake Manasarovar and Lake Rakshastal. The region covers an area of over $31,000 \mathrm{~km}^{2}$, including parts of far-western Nepal, northern India, and Purang County, Tibet Autonomous Region of China [23,38,39]. The elevation drop from the highest mountain, Naimona'nyi, to the southern parts is over $7000 \mathrm{~m}$. This loss in elevation causes abundant vegetation types, ranging from tropical broadleaved forest to alpine steppe. Diverse ecosystems provide habitats with rich biodiversity. The landscape is also home to 93 mammal species, 497 bird species, and 134 fish species, among other fauna, making it one of the ecologically richest areas in the western Himalayas [37].

Over a million people live within the landscape and most of this population resides in India and Nepal, with very few persons inhabiting the sparsely populated high-elevation areas on the Tibetan Plateau [37]. Local people rely heavily on the natural resources of this region. In KSL-China, grazing is the primary mode of utilization of grassland, often exerting pressures on fragile ecosystems. Agriculture accounts for a relatively small proportion of land use. In KSL-Nepal and KSL-India, forests cover large parts of these two regions and offer livelihoods to the local people while simultaneously supporting biodiversity conservation. Deforestation and fragmentation because of cropland expansion, infrastructure construction, and illegal timber harvesting have been reported in these regions. Forest cover loss and fragmentation are regarded as main causes of global ecosystem degradation [56]. Accordingly, human activities pose a serious threat to the fragile ecosystems in the KSL. 


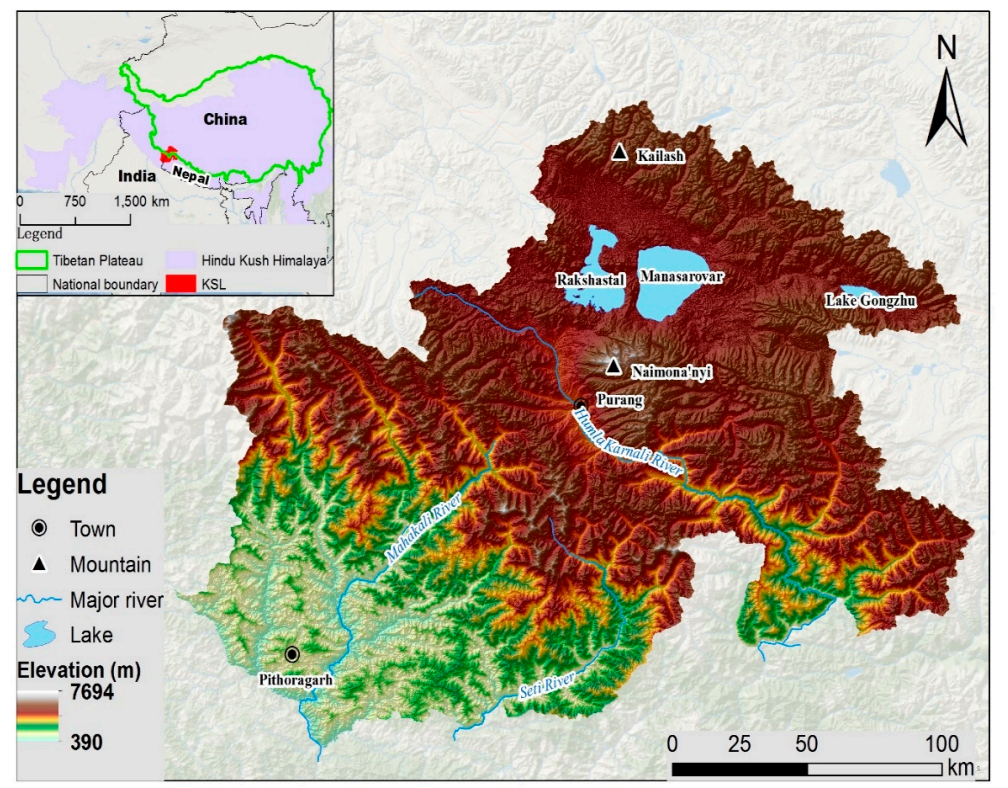

Figure 1. Map showing the location and topographic features of Kailash Sacred Landscape (KSL). The Hindu Kush Himalaya (HKH) boundary was obtained from https:/ /rds.icimod.org/home/ datadetail ?metadataid=3924 (accessed on 8 February 2021) and the Tibetan Plateau boundary from Zhang et al. 2014 [55].

\subsection{Classification System and Training Data Collection}

Land cover classification systems have been defined separately in KSL-China, KSLNepal, and KSL-India. Duan et al. [38] classified land cover in KSL-China into ten types: barren land, cropland, desert, glacier, wetland, water bodies, built-up land, low coverage rangeland, medium coverage rangeland, and high coverage rangeland. Uddin et al. [23] divided the land cover in the KSL-Nepal into seven types: forest, shrub land, grassland, cropland, barren area, water bodies, and snow/glacier. Singh et al. [39] classified the land cover system for KSL-India into seven types: forest, settlement, water, agriculture, grassland, scrubland, and snow. The landscape in KSL-China differs from that in KSLNepal and KSL-India, thus resulting in different land cover systems. Even though there is a certain resemblance in landscape between KSL-Nepal and KSL-India, differences exist in the classification systems. Following previous frameworks [57-59], we defined our land cover classification system as shown in Table 1. Land cover classes were defined through visual interpretation of high-resolution imagery available from Google Earth, using Landsat images as a reference. Visual interpretation of reference imagery was based on elements that help identify land cover features such as location, size, shape, tone/color, shadow, texture, and pattern [60]. Furthermore, considering the time intervals defined in this study, the training points that were stable during the study period were selected. Finally, we obtained all the defined land cover types and training points shown in Table 1 and Figure S1.

Table 1. Classification system and list of training points.

\begin{tabular}{ccc}
\hline Land Cover Code & Land Cover Type & Number of the Training Points \\
\hline 1 & Water bodies & 165 \\
2 & Snow/glacier & 255 \\
3 & Forest & 182 \\
4 & Built-up area & 80 \\
5 & Shrub land & 113 \\
6 & Cropland & 194 \\
7 & Grassland & 439 \\
8 & Barren land & 285 \\
9 & Wetland & 89 \\
\hline
\end{tabular}




\subsection{Preprocessing of the Landsat Images}

The Landsat-5 Thematic Mapper (TM), Landsat-7 Enhanced Thematic Mapper Plus (ETM+), and Landsat-8 Operational Land Imager (OLI) top-of-atmosphere (TOA) reflectance products were used for land cover change analysis (available online: https: / / earthengine.google.com (accessed on 8 February 2021)). The Landsat datasets covering our study area were then imported as image collections into GEE, a cloud-based geospatial analysis platform, for subsequent preprocessing tasks. Preprocessing methods presented by Alban et al. (2018) [61] were modified and applied in this study. The main preprocessing functions, including cloud masking, shadow masking, adding spectral index, etc., were packaged together. Using pixel-based image compositing methods, the best available observations from multiple Landsat images were selected to generate high-quality Landsat image composites for 2000 and 2015 [62-65]. Users can define parameters according to their own requirements, including location of the study area, composite years, cloud cover threshold, etc. The detailed parameters used in this study can be found in the supplementary materials. The quality of the image always suffers from high cloud cover, resulting in empty pixels or scenes. To solve this problem, we combined two strategies. First, we set the combine year parameter to three years to obtain as many images as possible; then we applied the focal_mean function offered by GEE (available at: https: / / developers.google.com/earth-engine (accessed on 8 February 2021)), a morphological mean filter, to each band of an image using a custom kernel (Figure S2). The detailed parameters used in this study can be found here: https:/ / code.earthengine.google.com/17f98d1e3fe5b7c0e6b432480a65dc9b (accessed on 8 February 2021).

\subsection{Classification Features Input and Classifier}

Multiple spectral indices have been developed to establish the relationship between the spectral and radiometric responses measured by remote sensors and the presence of various land covers, especially vegetation [66]. Huang et al. [67] used the B2-B7 and nominalized difference vegetation index (NDVI) bands as predicting bands for mapping land cover changes in Beijing; Teluguntla et al. [68] used the B2-B7 and NDVI bands as the classification features to map the 30-m cropland extent in Australia and China; and Xiong et al. [69] used B2-B4, B8, and NDVI bands as the predicting bands to acquire a 30-m resolution cropland extent map of continental Africa. Tsai et al. [44] mapped the LULC in Fanjingshan National Nature Reserve using the Landsat spectral band together with the NDVI, normalized difference blue and red (NDBR), normalized difference green and red (NDGR), normalized difference shortwave infrared and near-infrared (NDII), modified soil-adjusted vegetation index (MSAVI), and spectral variability vegetation index (SVVI).

To obtain the most suitable predicting bands, we added spectral bands as below: the B2-B7 and temp bands were selected as the main classification feature inputs, together with 15 spectral indices derived from the Landsat data, including the NDVI [70], the land surface water index (LSWI) [71], the nominalized difference snow index (NDSI) [72], the enhanced vegetation index (EVI) [73], the normalized difference tillage index (NDTI) [74], the normalized difference moisture index (NDMI) [75], the normalized burn ratio (NBR) [76], the vegetation index green (VIG) [77], tasseled cap transformation [78], and other spectral index (SI). These indices were defined as follows:

$$
\begin{gathered}
\text { NDVI }=\frac{\rho N I R-\rho \text { Red }}{\rho \text { NIR }+\rho \text { Red }} \\
\text { LSWI }=\frac{\rho \text { NIR }-\rho \text { SWIR1 }}{\rho \text { NIR }+\rho \text { SWIR1 }} \\
\text { NDSI }=\frac{\rho \text { Green }-\rho \text { SWIR1 }}{\rho \text { Green }+\rho \text { SWIR1 }}
\end{gathered}
$$




$$
\begin{aligned}
& \mathrm{EVI}=\frac{\rho \mathrm{NIR}-\rho \text { Red }}{\rho \text { NIR }+6 \times \rho \text { Red }-7.5 \times \rho \text { Blue }+1} \\
& \mathrm{NDTI}=\frac{\rho \mathrm{SWIR} 1-\rho \mathrm{SWIR} 2}{\rho \mathrm{SWIR} 1+\rho \mathrm{SWIR} 2} \\
& \mathrm{NDMI}=\frac{\rho N I R-\rho \mathrm{SWIR} 1}{\rho N I R+\rho \mathrm{WWIR} 1} \\
& \mathrm{NBR}=\frac{\rho N I R-\rho \mathrm{SWIR} 2}{\rho N I R+\rho \mathrm{SWIR} 2} \\
& \mathrm{VIG}=\frac{\rho \text { Green }-\rho \text { Red }}{\rho \text { Green }+\rho \text { Red }} \\
& \mathrm{SI}=\frac{\rho \text { Red }-\rho \text { Blue }}{\rho \text { Red }+\rho \text { Blue }}
\end{aligned}
$$

where $\rho$ NIR, $\rho$ Red, $\rho$ Green, $\rho$ SWIR1, $\rho$ SWIR2, and $\rho$ Blue represent the surface reflectance values of the near-infrared band $(0.76-0.9 \mu \mathrm{m})$, the red band $(0.63-0.69 \mu \mathrm{m})$, the green band $(0.52-0.6 \mu \mathrm{m})$, the shortwave infrared band $1(1.55-1.750 \mu \mathrm{m})$, the shortwave infrared band $2(2.11-2.29 \mu \mathrm{m})$, and the blue band $(0.45-0.52 \mu \mathrm{m})$ for a given pixel, respectively. Furthermore, we also took the topographical factors (slope, elevation, and aspects, available at: https: / / developers.google.com/earth-engine/datasets/catalog (available in EE as USGS/SRTMGL1_003) (accessed on 8 February 2021)) and nighttime data (available at: https:/ / developers.google.com/earth-engine/datasets/catlog/NOAA_VIIRS_DNB_ MONTHLY_V1_VCMSLCFG (accessed on 8 February 2021)) into consideration to better depict cropland and urban areas. We obtained a total of 24 features.

GEE provides 21 classifiers of which random forest (RF) is one of the most widely used as it yields higher classification accuracies, requires less model training time, and is less sensitive to training sample qualities compared to support vector machine (SVM) and artificial neural network (ANN) classifiers [79,80]. In this study, the RF classifier in GEE was trained using $70 \%$ of the training data randomly selected and extracted from the sets of image stacks, with the remaining $30 \%$ of the training data used for the model validation. A confusion matrix was implemented to assess the accuracy of the classified image with the independent set of ground truth points [81]. The overall accuracy was calculated in GEE, together with the producer's accuracy (PA) and user's accuracy (UA) of each land cover type. A previous study indicated that that the accuracy of a LULC map should higher than $85 \%$ for optimal interpretation and identification [82]. To deal with salt and pepper noise, classified images were postprocessed with a majority filter to smooth isolated pixels [83,84]. The overall levels of accuracy for 2000 and 2015 were $88.6 \%$ and $89.42 \%$, respectively. The $\mathrm{RF}$ classifier produced overall acceptable levels of accuracy for the four classification points in time and the defined LULC types (Tables S1 and S2).

\subsection{Detection of LULC Changes and Estimation of ESVS}

The LULC changes can be calculated using Equation (10). To identify the main conversion directions and highlight the dominant dynamic events in land use/cover changes, we used ArcGIS (version 10.4) to generate the transfer matrix for each period and visualized the transfer process with a Sankey Diagram (available online at: https: //sankey.csaladen.es (accessed on 8 February 2021)) [85,86]. The calculation is as follows:

$$
\mathrm{R}=\frac{L_{t}-L_{t-1}}{L_{t-1} * \Delta t} \times 100 \%
$$

where R represents the LULC change rate, $L_{t}$ represents land cover type in year $t, L_{t-1}$ represent land cover in the most recent time interval, and $\Delta t$ denotes the time interval (15 in this study).

To better understand the consequences of the conversion from forest to other LULC types, we further assessed the forest fragmentation of the KSL in 2000 and 2015 following 
the method described by Vogt et al. [87]. The forest LULC type was divided into six classes, patch, edge, perforated, small core (SC) ( $<250$ acres), medium core (MC) (250-500 acres), and large core (LC) ( $>500$ acres), by computing the distance from forest pixels to non-forest pixels. We defined the edge width as $100 \mathrm{~m}$ in reference to previous studies [23].

Costanza et al. [1] presented a model to estimate global ecosystem service value. However, this estimation method is best suited for Western countries; Xie et al. [88] therefore grouped the ESVs into four types and nine subtypes specific to China on this basis and using data from [5]. Costanza et al. [9] further presented a new method for the estimation of global ESVs and found that the ESVs of certain land cover types increased (e.g., the ESVs of forest land cover increased by 2462 USD per hectare per year from 1997-2011) while the remaining land cover types remained stable. In this study, we adopted the same equivalent value as that used by Song et al. [89] (Table 2). The equations used to evaluate the KSL's ESVs and their changes are as follow:

$$
\begin{gathered}
\mathrm{ESV}_{t}=\sum_{i=1}^{n} \text { Area }_{i} \times \mathrm{ESV}_{i} \\
\mathrm{C}_{\Delta t}=\frac{E_{\text {end }}-E_{\text {start }}}{E_{\text {Start }}} \times 100 \%
\end{gathered}
$$

where $\mathrm{ESV}_{t}$ denotes the total ESV at time $\mathrm{t}(2000,2005,2010,2015) ;$ Area $_{i}$ represents the area of land cover i, ESV $V_{i}$ represents the ESV of land cover I, and $\mathrm{n}$ denotes the total number of land cover types (seven types after reclassification in this study). $C_{t}$ represents the changes in ESV within a time interval (e.g., 2000-2005) and $E_{\text {end }}$ and $E_{\text {start }}$ denote the ESVs at the end and start of the time interval, respectively.

\begin{tabular}{|c|c|c|}
\hline Land Cover Defined in This Study & $\begin{array}{c}\text { Equivalent Biome } \\
\text { (Song et al. 2017) [89] }\end{array}$ & $\begin{array}{l}\text { ESVs Per Unit Area } \\
\left(\$ / \mathrm{hm}^{2} / \text { year }\right)\end{array}$ \\
\hline $\begin{array}{l}\text { Water bodies } \\
\text { Snow/glacier }\end{array}$ & Water areas & 2607.77 \\
\hline $\begin{array}{c}\text { Forest } \\
\text { Shrub land }\end{array}$ & Forestry areas & 1616.99 \\
\hline Grassland & Grassland & 671.06 \\
\hline Cropland & Cultivated land & 454.28 \\
\hline Built-up area & Built-up areas & 0 \\
\hline Barren land & Unused land & 79.93 \\
\hline Wetland & Wetland & 3149.45 \\
\hline
\end{tabular}

Table 2. Ecosystem service values (ESVs) of land cover types defined in this study.

\subsection{Elasticity of ESV Changes in Response to LULC Changes}

For the purpose of investigating the relation between LULC and ESVs, elasticity as defined by Song et al. [89] was applied in this study. The concept of elasticity is used to measure the sensitivity of a variable to change in another variable. Here, elasticity was used to measure the percentage change in ESV in relation to the percentage change in LULC, and thus can be described as follows:

$$
\begin{gathered}
\mathrm{EEl}=\left|\frac{\left(E_{\text {end }}-E_{\text {start }}\right) / E_{\text {start }} \times 100 \%}{L C P}\right| \\
\mathrm{LCP}=\frac{\sum_{i=1}^{7} \Delta L U T_{i}}{\sum_{i=1}^{7} L U T_{i}}
\end{gathered}
$$

where EEI represents the elasticity of ESV change in response to changes in LULC, $E_{\text {end }}$ is the ESV at the end of the study period, $E_{\text {start }}$ is the ESV at the beginning of the study period, LCP is the conversion percentage of land (which reveals both speed and degree of 
LULC conversion), $\triangle L U T_{i}$ is the converted area of the $i$ type of LULC, $L U T_{i}$ is the area of the $i$ type of LULC, and Tis the time gap (in years) of the study period.

\section{Results}

\subsection{The Spatial Distribution of LULC and Its Changes}

As shown in Figure 2, there was a significant difference in land cover between the Himalayan northern slopes (China side) and southern slopes (Nepal and India side). Statistical results indicated that most land in the KSL was covered by grassland $(23.98 \%$ in $2000,25.74 \%$ in 2015 ) followed by barren land (21.34\% in 2000, $21.98 \%$ in 2015$)$, and forest $(17.45 \%$ in $2000,16.04 \%$ in 2015$)$ (Table 3). Grassland was mainly distributed in KSL-China and widely distributed on the Tibetan Plateau (55.73\% in 2000, 52.84\% in 2015). Over 60\% of barren land was distributed in KSL-China and forest land cover was mainly distributed in KSL-Nepal and KSL-India (60.69\% and $39.31 \%$ in 2000 , respectively). Snow/glacier accounted for more than $15.16 \%$ of the total area and over $53 \%$ of snow/glacier was distributed in KSL-Nepal (54.14\% in 2000, 53.61\% in 2015). Cropland and built-up areas were the main land cover types closely relevant to human activities and these were mainly distributed in KSL-Nepal and KSL-India.

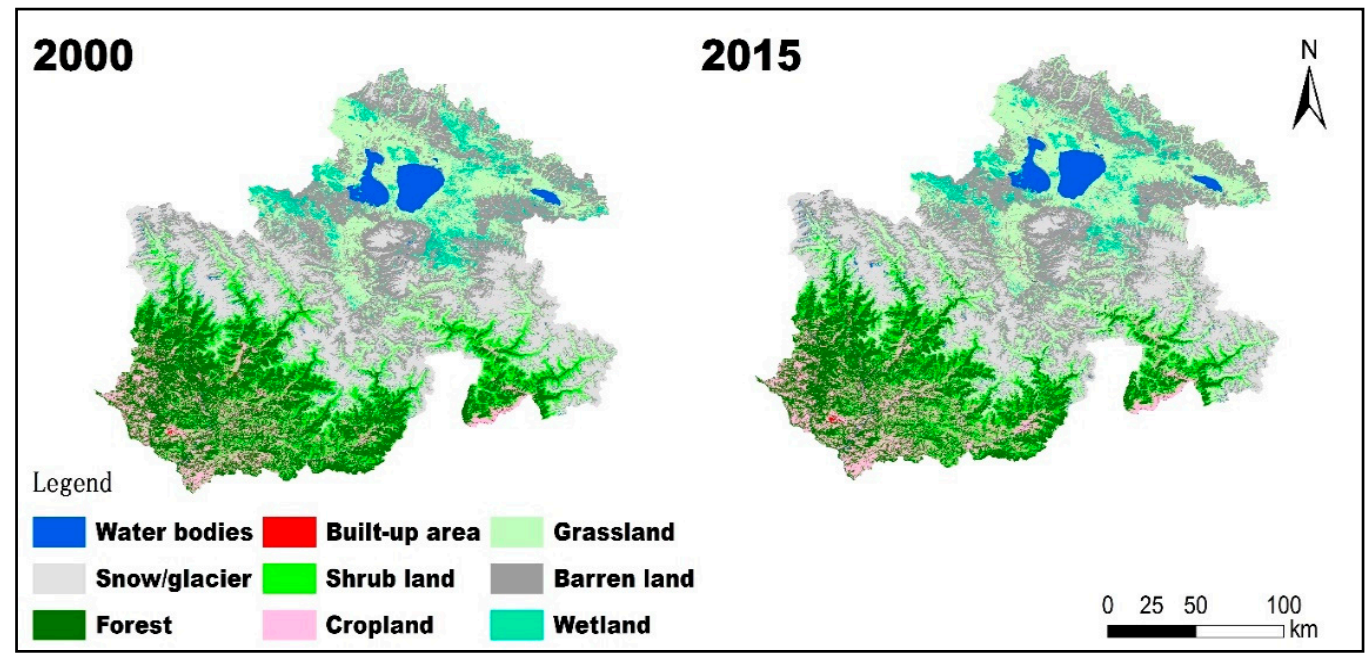

Figure 2. The distribution of different land cover types in KSL in 2000 and 2015.

Table 3. Land use and land cover (LULC) in the KSL during the period 2000-2015.

\begin{tabular}{ccccccc}
\hline Land Cover & Area in $\mathbf{2 0 0 0}\left(\mathbf{k m}^{\mathbf{2}}\right)$ & $\mathbf{\%}$ & Area in $\mathbf{2 0 1 5} \mathbf{( k m}^{\mathbf{2}} \mathbf{n}$ & $\mathbf{\%}$ & $\begin{array}{c}\text { Changed Area } \\
\mathbf{( 2 0 0 0 - 2 0 1 5 )}\end{array}$ & $\begin{array}{c}\text { Change Rate } \\
\mathbf{( 2 0 0 0 - 2 0 1 5 )}\end{array}$ \\
\hline Water bodies & 990.27 & 3.17 & 994.71 & 3.19 & 4.43 & 0.03 \\
Snow / glacier & 4728.51 & 15.16 & 4687.55 & 15.03 & -40.96 & -0.06 \\
Forest & 5443.20 & 17.45 & 5003.37 & 16.04 & -439.82 & -0.54 \\
Built-up area & 65.59 & 0.21 & 66.05 & 0.21 & 0.46 & 0.05 \\
Shrub land & 2917.78 & 9.35 & 2528.17 & 8.11 & -389.61 & -0.89 \\
Cropland & 1910.59 & 6.13 & 2257.50 & 7.24 & 346.90 & 1.21 \\
Grassland & 7479.89 & 23.98 & 8028.35 & 25.74 & 548.46 & 0.49 \\
Barren land & 6655.26 & 21.34 & 6854.46 & 21.98 & 199.20 & 0.20 \\
Wetland & 1000.04 & 3.21 & 770.98 & 2.47 & -229.07 & -1.53 \\
Total & $31,191.13$ & 100 & $31,191.13$ & 100 & & \\
\hline
\end{tabular}

Between 2000 and2015, four land cover types showed decreasing trends and the other five land cover types showed increasing trends (Table 3). The greatest loss was found for forest: a total of $439.82 \mathrm{~km}^{2}$ forest cover loss was observed in the KSL. The decrease of forest cover in KSL-Nepal contributed $89.68 \%$ of the total forest loss during the research period. Shrub land also showed an obvious decreasing trend, with a total loss of $389.61 \mathrm{~km}^{2}$ during 
the research period, decreasing at a rate of $0.89 \%$ per year. The decrease of shrub land in KSL-Nepal and KSL-India contributed $65.55 \%$ and $34.3 \%$, respectively, to the total shrub land loss. During the research period, wetland and snow/glacier decreased by $229.07 \mathrm{~km}^{2}$ and $40.96 \mathrm{~km}^{2}$, respectively. Among the land cover types with increasing trends, the biggest gains were found in grassland: grassland increased by $548.46 \mathrm{~km}^{2}$ during the research period. The increase in grassland in KSL-Nepal and KSL-India contributed 58.32\% and $28.22 \%$ to the total gains in grassland in the KSL, respectively. From 2000-2015, cropland increased by $346.90 \mathrm{~km}^{2}$ and at a rate of $1.21 \%$ per year. The biggest increase was observed in KSL-Nepal, where cropland increased by $247.94 \mathrm{~km}^{2}$ from $2000-2015$. Barren land was found to increase from $6655.26 \mathrm{~km}^{2}$ to $6854.46 \mathrm{~km}^{2}$ between 2000 and 2015 and at a rate of $0.2 \%$ per year. Changes in water bodies and built-up areas were not obvious and only increased by $4.43 \mathrm{~km}^{2}$ and $0.46 \mathrm{~km}^{2}$, respectively, during the research period. The results indicate that the area of land types with higher ecosystem service values (e.g., forest, shrub land, and wetland) decreased.

Forest, barren land and grassland were significantly converted to other land cover types in the period from 2000-2015 (Table 4 and Figure 3). A total of $857.81 \mathrm{~km}^{2}$ of forest were converted to other land cover types, including 59.18\% that were converted to shrub land and $34.19 \%$ that were converted to cropland. This indicates the forest fragmentation occurred between 2000 and 2015. About $1125.07 \mathrm{~km}^{2}$ of barren land were converted into other land cover types during the research period, $39.96 \%$ of which were converted to snow/glacier. Snow/glacier mainly converted to barren land during the research period: a total of $526.78 \mathrm{~km}^{2}$ of snow/glacier were converted to barren land. About $1150.91 \mathrm{~km}^{2}$ of grassland were converted to other land cover types with $61.17 \%$ converted to barren land. During the study period, shrub land contributed most to the expansion of cropland: a total of $425.48 \mathrm{~km}^{2}$ of shrub land was converted to cropland. Meanwhile, cropland mainly converted to shrub land and forest between 2000 and 2015: a total of $288.38 \mathrm{~km}^{2}$ and $170.74 \mathrm{~km}^{2}$ of cropland converted to shrub land and forest, respectively. The expansion of built-up areas was mainly at the cost of cropland. The results indicate that deforestation and cropland abandonment occurred in KSL-Nepal and KSL-India simultaneously.

Table 4. Transition matrix of different LULC types in the KSL during the period 2000-2015.

\begin{tabular}{|c|c|c|c|c|c|c|c|c|c|}
\hline \multirow[b]{2}{*}{2015} & \multicolumn{9}{|c|}{2000} \\
\hline & $\begin{array}{l}\text { Water } \\
\text { Bodies }\end{array}$ & $\begin{array}{l}\text { Snow/ } \\
\text { Glacier }\end{array}$ & Forest & $\begin{array}{c}\text { Built-up } \\
\text { Area }\end{array}$ & $\begin{array}{l}\text { Shrub } \\
\text { Land }\end{array}$ & Cropland & Grassland & $\begin{array}{c}\text { Barren } \\
\text { Land }\end{array}$ & Wetland \\
\hline Water bodies & 832.23 & 61.02 & 19.24 & 4.54 & 4.40 & 0.91 & 32.87 & 35.5 & 0.00 \\
\hline Snow/glacier & 48.92 & 4068.60 & 2.66 & 2.43 & 3.55 & 0.27 & 76.05 & 526.78 & 0.70 \\
\hline Forest & 7.87 & 0.09 & 4586.69 & 8.21 & 507.66 & 293.25 & 39.95 & 0.79 & 0.00 \\
\hline Built-up area & 7.74 & 0.06 & 6.49 & 23.11 & 1.40 & 25.02 & 1.39 & 0.49 & 0.00 \\
\hline Shrub land & 16.12 & 31.59 & 203.00 & 0.85 & 1641.12 & 425.48 & 588.14 & 11.69 & 0.00 \\
\hline Cropland & 1.59 & 0.02 & 170.74 & 10.41 & 288.38 & 1420.75 & 17.31 & 1.62 & 0.24 \\
\hline Grassland & 29.40 & 77.80 & 13.99 & 8.32 & 79.91 & 75.55 & 6329.91 & 704.02 & 161.93 \\
\hline Barren land & 51.32 & 449.60 & 1.83 & 8.22 & 1.94 & 3.48 & 555.73 & 5531.32 & 52.95 \\
\hline Wetland & 0.00 & 0.32 & 0.00 & 0.03 & 0.00 & 13.31 & 387.99 & 43.23 & 555.29 \\
\hline
\end{tabular}




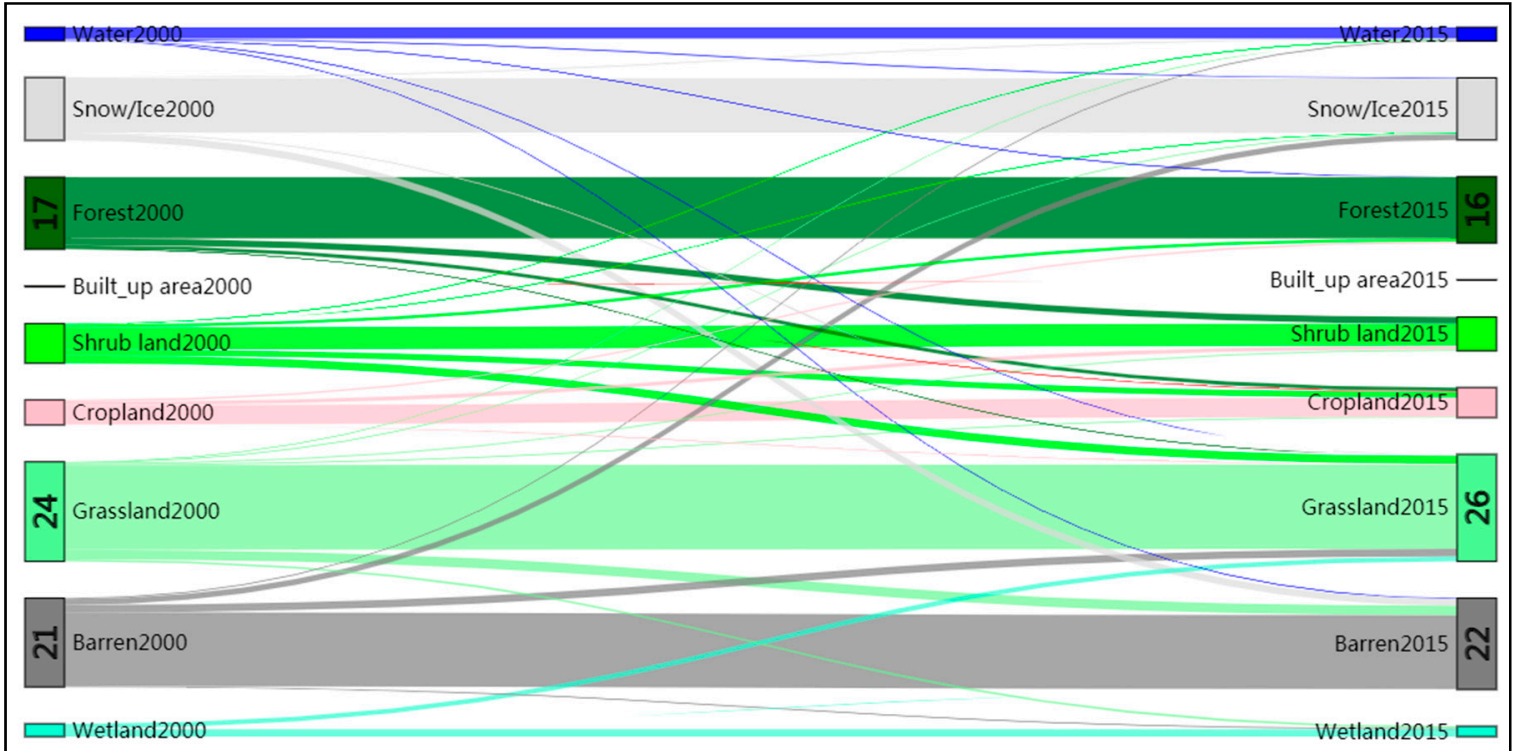

Figure 3. Sankey diagram of LULC transitions in the KSL during the period 2000-2015. The map was created using the tool at https://sankey.csaladen.es/\#.

\subsection{Forest Fragmentation in the KSL}

A conversion of forest to other land cover types indicating forest fragmentation occurred in the KSL during the research period (Table 5). The distribution of and changes in forest fragmentation in 2000 and 2015 are depicted in Figure 4. During the study period, the forest fragmentation changed significantly. In 2000, core forest ( $>500$ acres) covered $34.24 \%$ of the forest area, followed by edge forest covering $30.39 \%$, perforated forest covering $18.44 \%$, core forest ( $<250$ acres) covering $7.72 \%$, patch forest covering $5.95 \%$, and core forest (250-500 acres) covering $2.89 \%$. In 2015, edge forest covered $33.67 \%$ of the forest area, followed by core forest ( $>500$ acres) covering $28.1 \%$, perforated forest covering $17.22 \%$, patch forest covering $8.69 \%$, core forest ( $<250$ acres) covering $8.53 \%$, and core forest (250-500 acres) covering $3.79 \%$. Core forest (>500 acres) decreased from $1883.90 \mathrm{~km}^{2}$ to $1406.05 \mathrm{~km}^{2}$, with a change rate of $25.36 \%$. Meanwhile, patch forest increased from $323.81 \mathrm{~km}^{2}$ to $434.83 \mathrm{~km}^{2}$, with a change rate of $34.29 \%$.

Table 5. Forest fragmentation and change in KSL between 2000 and 2015.

\begin{tabular}{|c|c|c|c|c|}
\hline Type of Patches & $\begin{array}{c}2000 \\
\left(\mathrm{~km}^{2}\right)\end{array}$ & $\begin{array}{c}2015 \\
\left(\mathrm{~km}^{2}\right)\end{array}$ & $\begin{array}{c}2000-2015 \\
\left(\mathrm{~km}^{2}\right)\end{array}$ & $\begin{array}{c}\text { Change Rate } \\
(\%)\end{array}$ \\
\hline Patch & 323.81 & 434.83 & 111.02 & 34.29 \\
\hline Edge & 1654.24 & 1684.39 & 30.15 & 1.82 \\
\hline Perforated & 1003.80 & 861.59 & -142.21 & -14.17 \\
\hline Core (<250 acres) & 420.12 & 426.81 & 6.69 & 1.59 \\
\hline Core (250-500 acres) & 157.33 & 189.71 & 32.37 & 20.58 \\
\hline Core (>500 acres) & 1883.90 & 1406.05 & -477.85 & -25.36 \\
\hline
\end{tabular}




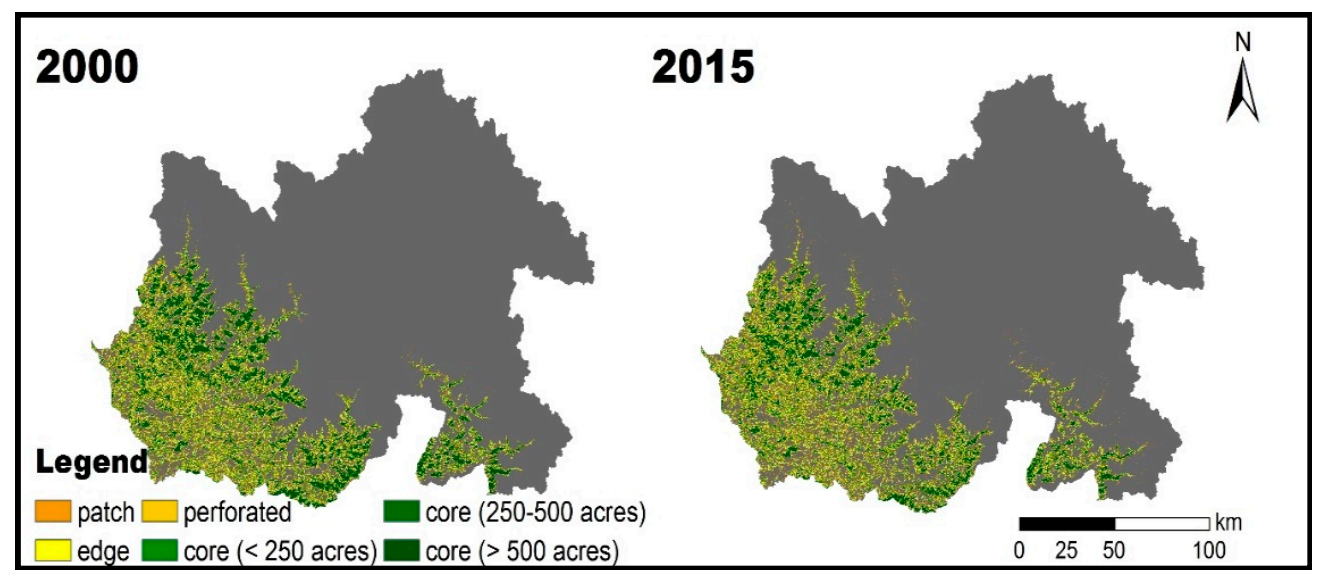

Figure 4. Forest fragmentation maps from 2000 and 2015. Core-relatively distant from the forestnon-forest boundary; patch—forests too small to be considered as core forest; perforated-boundaries between core forest and relatively small perforations; edge-boundaries of relatively large perforations and the exterior boundaries of core forest regions.

Forest land cover was mainly distributed in KSL-Nepal; this also true for the core forest ( $>500$ acres), covering $57.68 \%$ of the total core forest ( $>500$ acres) in KSL. In 2000, core forest ( $>500$ acres) covered $32.90 \%$ of the forest area in KSL-Nepal, followed by edge forest covering $31.23 \%$, perforated forest covering $18.28 \%$, core forest ( $<250$ acres) covering $8.24 \%$, patch forest covering $6.12 \%$, and core forest (250-500 acres) covering $3.23 \%$. During the research period, core forest ( $>500$ acres) decreased by $31.97 \%$ and patch forest increased by $38.62 \%$. The rest of the forest land cover was distributed in KSL-India. In 2000, core forest $(>500$ acres) covered $37.25 \%$ of the forest area in KSL-India, followed by edge forest covering $29.09 \%$, perforated forest covering $18.70 \%$, core forest ( $<250$ acres) covering $6.91 \%$, patch forest covering $5.68 \%$, and core forest (250-500 acres) covering 2.36\%. From 2000-2015, core forest ( $>500$ acres) decreased by $16.36 \%$ and core forest (250-500acrs) increased by $56.59 \%$. The results suggest that deforestation and forest fragmentation occurred in KSL, especially in KSL-Nepal, during the research period.

\subsection{The LULC Changes in KSL-China, KSL-Nepal, and KSL-India}

In 2015, most land in the three countries was covered by different land cover types (Table 6). In KSL-China, barren land accounted for the largest proportion of land cover. During the research period, no evident changes were observed in barren land (increase of $2.43 \mathrm{~km}^{2}$ ). As the second largest land cover type, grassland increased from $4168.41 \mathrm{~km}^{2}$ to $4242.24 \mathrm{~km}^{2}$ during the research period. Between 2000 and 2015, snow/glacier increased from $756.58 \mathrm{~km}^{2}$ to $815.46 \mathrm{~km}^{2}$, an increasing trend opposite to the broader picture for KSL snow/glacier. A great increase was observed in cropland, which increased by $73.07 \mathrm{~km}^{2}$ between 2000 and 2015. Wetland, water bodies and shrub land showed decreasing trends during the research period, while the largest decrease was found in wetland (decreased by $203.29 \mathrm{~km}^{2}$ ). In KSL-Nepal, grassland, cropland, and barren land contributed most to land cover increases. During the research period, the greatest gains were found in grassland, which increased by $319.87 \mathrm{~km}^{2}$, followed by cropland, which contributed the most to the cropland expansion in the KSL (increase of $247.94 \mathrm{~km}^{2}$, accounting for over $70 \%$ of the total increase). Forest in KSL-Nepal decreased from $3303.37 \mathrm{~km}^{2}$ to $2908.90 \mathrm{~km}^{2}$ during the research period. Between 2000 and 2015, shrub land decreased by $255.43 \mathrm{~km}^{2}$, second only to the loss of forest. Snow/glacier showed a decreasing trend and decreased by $47.31 \mathrm{~km}^{2}$ during the research period. In KSL-India, the greatest gains were found for grassland, which increased by $154.76 \mathrm{~km}^{2}$ between 2000 and 2015. Changes in cropland were not evident, with an increase from $796.86 \mathrm{~km}^{2}$ to $822.83 \mathrm{~km}^{2}$. Shrub land decreased from $905.79 \mathrm{~km}^{2}$ to $772.13 \mathrm{~km}^{2}$ during the research period. The most significant changes 
were observed for cropland expansion and forest loss, which were mainly distributed in KSL-Nepal.

Table 6. Dynamic changes in LULC types between 2000-2015.

\begin{tabular}{|c|c|c|c|c|c|c|c|c|c|c|c|c|}
\hline \multirow[b]{2}{*}{ Land Cover } & \multicolumn{4}{|c|}{ KSL-China } & \multicolumn{4}{|c|}{ KSL-Nepal } & \multicolumn{4}{|c|}{ KSL-India } \\
\hline & $\begin{array}{c}2000 \\
\left(\mathrm{~km}^{2}\right)\end{array}$ & $\begin{array}{c}2015 \\
\left(\mathrm{~km}^{2}\right)\end{array}$ & $\begin{array}{c}\text { Change } \\
\text { Area } \\
\left(\mathrm{km}^{2}\right)\end{array}$ & $\begin{array}{c}\text { Change } \\
\text { Rate } \\
(\%)\end{array}$ & $\begin{array}{c}2000 \\
\left(\mathrm{~km}^{2}\right)\end{array}$ & $\begin{array}{c}2015 \\
\left(\mathrm{~km}^{2}\right)\end{array}$ & $\begin{array}{c}\text { Change } \\
\text { Area } \\
\left(\mathrm{km}^{2}\right)\end{array}$ & $\begin{array}{c}\text { Change } \\
\text { Rate } \\
(\%)\end{array}$ & $\begin{array}{c}2000 \\
\left(\mathrm{~km}^{2}\right)\end{array}$ & $\begin{array}{c}2015 \\
\left(\mathrm{~km}^{2}\right)\end{array}$ & $\begin{array}{c}\text { Change } \\
\text { Area } \\
\left(\mathrm{km}^{2}\right)\end{array}$ & $\begin{array}{c}\text { Change } \\
\text { Rate } \\
(\%)\end{array}$ \\
\hline $\begin{array}{l}\text { Water } \\
\text { bodies }\end{array}$ & 754.55 & 748.52 & -6.03 & -0.05 & 136.44 & 15007 & 13.64 & 0.67 & 99.45 & 96.30 & -3.15 & -0.21 \\
\hline Snow/glacier & 756.58 & 815.46 & 58.89 & 0.52 & 2560.67 & 2513.36 & -47.31 & -0.12 & 1412.07 & 1359.45 & -52.63 & -0.25 \\
\hline Forest & 0.00 & 0.00 & 0.00 & 0.00 & 3303.37 & 2908.90 & -394.47 & -0.80 & 2140.04 & 2094.67 & -45.38 & -0.14 \\
\hline $\begin{array}{c}\text { Built-up } \\
\text { area }\end{array}$ & 0.15 & 1.83 & 1.69 & 75. & 2 & 6 & -0.67 & -0.14 & 3 & 32.04 & -0.56 & -0.11 \\
\hline Shrub land & 0.63 & 0.05 & -0.58 & -6.17 & 2011.52 & 1756.09 & -255.43 & -0.85 & 905.79 & 772.13 & -133.66 & -0.98 \\
\hline Cropland & 13.61 & 86.67 & 73.07 & 35.80 & 1100.41 & 1348.35 & 247.94 & 1.50 & 796.86 & 822.83 & 25.97 & 0.22 \\
\hline Grassland & 4168.41 & 4242.24 & 73.83 & 0.12 & 2358.69 & 2678.55 & 319.87 & 0.90 & 952.65 & 1107.41 & 154.76 & 1.08 \\
\hline Barren land & 4227.39 & 4229.81 & 2.43 & 0.00 & 1659.08 & 1801.75 & 142.67 & 0.57 & 767.51 & 821.74 & 54.23 & 0.47 \\
\hline Wetland & 898.35 & 695.06 & -203.29 & -1.51 & 97.66 & 71.42 & -26.24 & -1.79 & 4.08 & 4.49 & 0.41 & 0.68 \\
\hline
\end{tabular}

\subsection{The Spatial Distribution of ESVs and Their Response to LULC Changes}

The ESVs of the KSL in 2000 and 2015 were estimated (Figure 5 and Table 7). The total ESV of the KSL in 2000 was $36.53 \times 10^{8} \mathrm{USD}^{-1}$. During the research period, the total ESV decreased by $1.17 \times 10^{8} \mathrm{USD}^{-1}$. In general, water areas and forestry areas contributed most to the total ESV, accounting for about $77.83 \%$ in 2000 and $76.38 \%$ in 2015 . In 2000, water areas contributed about $40.82 \%$ of the total ESV in the KSL and $41.91 \%$ in 2015 . Forestry areas contributed the second most to the total ESV and decreased from $13.52 \times 10^{8} \mathrm{USD} \mathrm{y}^{-1}$

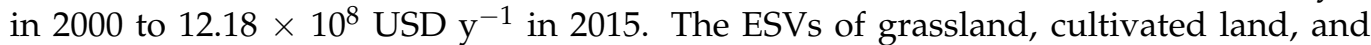
unused land showed an increasing trend. The greatest gains were found in grassland: the ESV of grassland increased from $5.42 \times 10^{8} \mathrm{USD} \mathrm{y}^{-1}$ to $5.67 \times 10^{8} \mathrm{USD} \mathrm{y}^{-1} \mathrm{during}^{-1}$ the research period. With the expansion of cropland, the ESV of cropland increased by $0.16 \times 10^{8}$ USD $^{-1}$ from 2000-2015. Although wetland accounted for a small area in the KSL, the high ESV of wetland enlarged its influence on the total ESV. During the research period, the ESV of wetland decreased by $0.16 \times 10^{8} \mathrm{USD}_{\mathrm{y}}{ }^{1}{ }^{1}$, which offset the increase of ESV of cropland. Since the ESV of built-up areas was zero, this kind of land cover contributed no ESV.

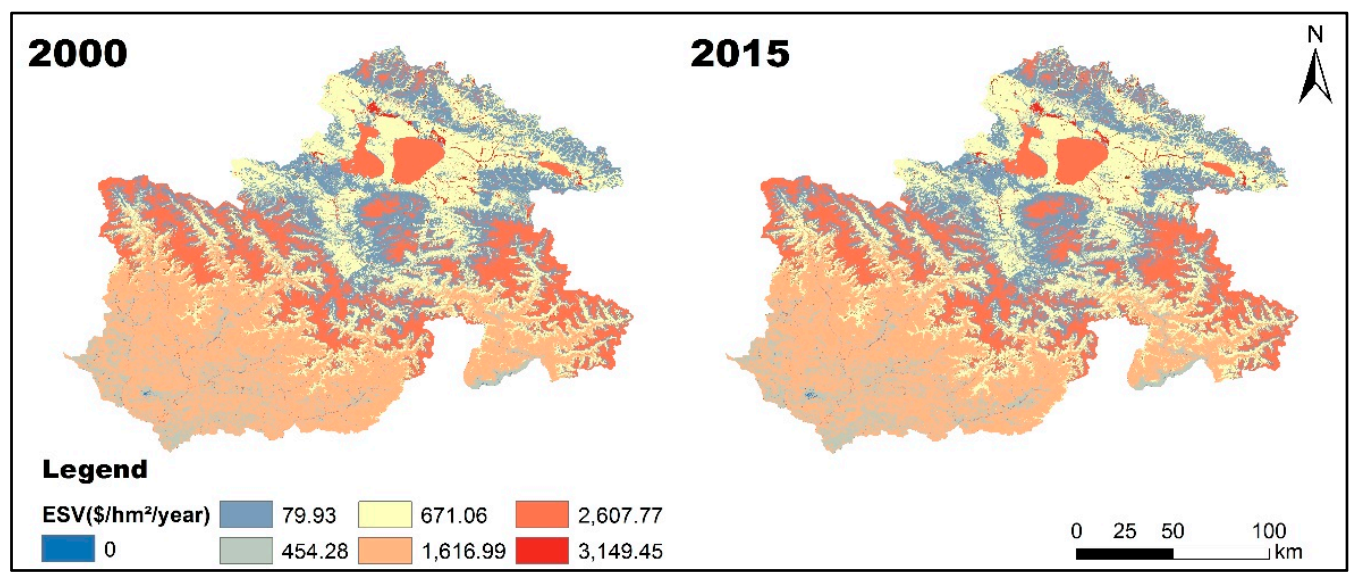

Figure 5. The distribution of ESVs in the KSL in 2000 and 2015. 
Table 7. The ESVs of 11 LULC types in 2000 and 2015.

\begin{tabular}{|c|c|c|c|c|}
\hline \multirow[t]{2}{*}{ Land Cover } & \multicolumn{2}{|c|}{$\begin{array}{c}\text { Value } \\
\left(10^{8} \text { USD }^{-1}\right)\end{array}$} & \multirow{2}{*}{$\begin{array}{c}\text { Change Value } \\
\left(10^{8} \text { USD y }^{-1)}\right. \\
2000-2015\end{array}$} & \multirow{2}{*}{$\begin{array}{c}\begin{array}{c}\text { Change Rate } \\
\text { (\%) }\end{array} \\
2000-2015\end{array}$} \\
\hline & 2000 & 2015 & & \\
\hline Water areas & 14.91 & 14.82 & -0.09 & -0.6 \\
\hline Forestry area & 13.52 & 12.18 & -1.34 & -9.91 \\
\hline Grassland & 5.42 & 5.67 & 0.25 & 4.61 \\
\hline Cultivated land & 0.87 & 1.03 & 0.16 & 18.39 \\
\hline Built-up areas & 0 & 0 & 0 & 0 \\
\hline Unused land & 0.53 & 0.55 & 0.02 & 3.77 \\
\hline Wetland & 1.28 & 1.12 & -0.16 & -12.50 \\
\hline Total & 36.53 & 35.35 & -1.17 & -3.20 \\
\hline
\end{tabular}

In KSL-China, the total ESV was $8.44 \times 10^{8} \mathrm{USD}^{-1}$ in 2000 , lower than the ESVs in KSL-Nepal $\left(18.07 \times 10^{8} \mathrm{USD} \mathrm{y}^{-1}\right)$ and KSL-India $\left(10.03 \times 10^{8} \mathrm{USD} \mathrm{y}^{-1}\right)$. Water bodies contributed most to the total ESV in China, accounting for almost half of the total ESV in KSL-China, followed by Grassland $\left(3.20 \times 10^{8} \mathrm{USD}^{-1}\right)$. From 2000-2015, the total ESV in KSL-China increased by $0.06 \times 10^{8} \mathrm{USD} \mathrm{y}^{-1}$. The increase of water bodies by $0.13 \times 10^{8} \mathrm{USD} \mathrm{y}^{-1}$ contributed most to the increase of the total ESV in KSL-China. The decrease of the ESV of grassland was the main cause for the decrease of total ESV in the KSL. The ESV of wetland decreased from $0.95 \times 10^{8}$ USD y $^{-1}$ in 2000 to $0.93 \times 10^{8}$ USD y $^{-1}$ in 2015. In KSL-Nepal, the total ESV accounted for about $50 \%$ of the total ESV in the KSL. During the research period, ESV in KSL-Nepal decreased by $0.88 \times 10^{8} \mathrm{USD}^{-1}$; the decrease of the ESVs of forestry areas was the main cause of the loss of total ESV in KSL-Nepal. In 2000, the ESVs of forestry areas accounted for $47.54 \%$ of the total ESV in KSLNepal. However, this number decreased to $43.87 \%$ in 2015. From 2000-2015, the ESV of forestry areas decreased by $1.05 \times 10^{8} \mathrm{USD}^{-1}$. The ESVs of cultivated land and grassland increased by $0.11 \times 10^{8} \mathrm{USD} \mathrm{y}^{-1}$ and $0.21 \times 10^{8} \mathrm{USD} \mathrm{y}^{-1}$, respectively, and offset a small part of the ESV loss. In KSL-India, the total ESV decreased from $10.03 \times 10^{8} \mathrm{USD}^{-1}$ in 2000 to $9.67 \times 10^{8}$ USD $^{-1}$ in 2015 . The ESV of forestry areas contributed most to the total ESV in KSL-India, similar to KSL-Nepal, followed by water areas. The greatest loss was observed in forestry areas: the ESV of forestry areas decreased by $0.29 \times 10^{8} \mathrm{USD}^{-1}$. From 2000 to 2015, the ESV of water areas decreased by $0.15 \times 10^{8}$ USD y $^{-1}$, second only to the loss in ESV of forestry areas. The greatest gains in ESV were found for grassland, which increased by 0.12 during the research period. The small changes of cropland in KSL-India made a relevant but small contribution to the changes in ESV in KSL-India.

The elasticity of ESV change with respect to LULC changes during the research period was 2.33 , which indicates that a conversion of $1 \%$ of land area would result in an average change of $2.33 \%$ in the ESV. The elasticity of the ESVs in the three countries was further calculated. The results show that KSL-China had the highest elasticity at 5.27, indicating that a conversion of $1 \%$ of land area would result in an average change of $5.27 \%$ in the ESV. In KSL-Nepal, the elasticity was 4.34, higher than that of KSL-India (1.57).

\section{Discussion}

\subsection{LULC Changes across the KSL}

Detailed LULC research is of great significance for managing natural resource effectively [23]. In this study, we applied an RF algorithm to classify the LULC in the KSL in 2000 and 2015 using GEE. For a solution to the problem of the low-quality imagery caused by the high cloud cover in this region, we adopted a pixel-based image composite algorithm and filled the blank pixels using the focal_mean function. Furthermore, the spectral index, terrain factors, and nighttime light data were used to improve the accuracy of the classification. The entire process of LULC classification, except where otherwise noted, was accomplished in GEE. The overall accuracies of the LULC classification in 2000 and 2015 were $87.69 \%$ and $85.73 \%$, respectively, indicating the good performance of our 
methods. Based on the LULC, we further estimated the ESVs of the KSL and qualified the responses of ESVs to LULC changes.

During the research period, the greatest land cover loss was found for forest cover, which decreased by $439.82 \mathrm{~km}^{2}$. Forest area in Nepal and India decreased from $3303.37 \mathrm{~km}^{2}$ to $2908.90 \mathrm{~km}^{2}$ and from $2140.04 \mathrm{~km}^{2}$ to $2094.67 \mathrm{~km}^{2}$, respectively. The same phenomenon of forest cover decrease has also been found in other Himalayan regions [90,91]. The second greatest land cover loss was found for shrub land, which decreased by $389.61 \mathrm{~km}^{2}$ between 2000 and 2015. These decreasing vegetated areas, especially the forest cover loss, may pose a threat to biodiversity conservation and livelihood [92,93]. Meanwhile, grassland and cropland areas significantly increased during the research period, which is consistent with the findings of Uddin et al.'s [23] and Singh et al. [39]. Cropland increased from $1910.59 \mathrm{~km}^{2}$ to $2257.50 \mathrm{~km}^{2}$, with a change rate of $1.21 \%$ per year. The three countries showed the same increasing trend. The largest growth was found in Nepal, where cropland increased by $247.94 \mathrm{~km}^{2}$. Results from the transfer matrix show that expansions of cropland were mainly derived from forest and shrub land in KSL-India and KSL-Nepal. It has been previously shown that expansion of cropland is one of the major drivers of deforestation in the Himalayas [94]. Through statistical analysis of the LULC changes along the elevation, we further found that the increase of cropland was mainly distributed between 1000 and $2500 \mathrm{~m}$ in the KSL, accounting for $79.63 \%$ of the total increase (Figure S3). The largest growth was found at $1500-2000 \mathrm{~m}$, accounting for $35.01 \%$. The decrease of forest was mainly distributed between 1000 and $3500 \mathrm{~m}$, accounting for $99.28 \%$ of the total loss. The most passive change of forest cover was between 1500 and $2000 \mathrm{~m}$. An earlier study has shown that, in the final three decades of the 20th century, forest degradation mainly occurred in temperate oak forests at elevations of 1800-2800 m, with some forests also lost at lower elevations [95]. Lowland areas are considered more favorable for supporting human livelihood and thus result in more intense LULC changes [96].

The forest in the KSL is undergoing a process of fragmentation under the drivers of cropland expansion and illegal timber extraction [23,39]. As an important habitat for countless wild species, the decrease in forest cover along with forest fragmentation put wild life in danger. Sarker et al. (2018) assessed the habitat suitability and connectivity of the common leopard (Panthera pardus) in Kailash Sacred Landscape [97]. Their results show that the best forest connectivity for leopards lies between large forest patches situated at the middle elevational range of the landscape, associated with moderate to medium slopes and a high density of rivers and streams. The decrease in core forest cover may threaten the habitat of the common leopard. Increasing human activities (expansion of cropland and built-up areas) [98,99], together with climate change [100], have resulted in rapid changes in the Himalayan ecosystem [101]. Invasive species are another important issue to consider. Research has shown that species, including invasive species, tend to move to higher elevation regions in global warming contexts [102,103].

The conversion of cropland to forest and shrub land indicates that farmland abandonment occurred in the KSL. Between 2000 and 2015, $288.38 \mathrm{~km}^{2}$ of cropland were converted to shrub land. A noticeable increasing trend in farmland abandonment has been reported all around the world, especially in mountain regions [104,105]. According to a previous study, the hill and mountain regions of the Nepal Himalayas are more prone to farmland abandonment because of labor migration [106-108]. Singh et al. (2015) also found that, in KSL-India, continuous migration forced the conversion of high-altitude agricultural lands into grasslands and scrublands [39]. From the perspective of ecosystems service, farmland abandonment itself has positive effects [109]; however, it also poses a threat to the food security of local livelihoods [107].

\subsection{ESV Changes in Response to LULC Changes}

LULC changes are generally accepted as one of the critical drivers of global change [110]. During the studied 15-year period, the total ESV of the KSL decreased from $36.53 \times 10^{8} \mathrm{USD} \mathrm{y}^{-1}$ to $35.35 \times 10^{8} \mathrm{USD} \mathrm{y}^{-1}$, decreasing at a rate of $0.21 \%$ /year. The decrease of forestry areas was 
the primary cause for the loss of ESV. The largest ESVs were observed in KSL-Nepal, due to the large forestry areas, whereas KSL-China was responsible for the smallest proportion of the ESV. However, the ESVs in KSL-China showed an inverse trend compared to KSL-Nepal and KSL-India. Between 2000 and 2015, the total ESV of KSL-China increased by $0.06 \times 10^{8} \mathrm{USD} \mathrm{y}^{-1}$ thanks to the increase in water areas. On a global scale, the global terrestrial ESV decreased at a rate of 2.06\%/year from 1997 to 2011 [9]. Hence, changes in ESVs in the KSL were more modest than those globally. On a national scale, the terrestrial ESVs in China decreased at a rate of 0.03\% per year from 1988-2008. This indicates that the decreases in ESVs in KSL were much more rapid. However, there are large gaps in other Himalayan regions. Bhaskar et al. [111] assessed the ESVs in the Transboundary Karnali River Basin (KRB), Central Himalayas, and showed that they increased by


the increase of ESVs in this region, followed by bare land. Raju et al. [112] estimated the ESVs in the Transboundary Gandaki River Basin (GRB), Central Himalayas, indicating that there was a $1.68 \times 10^{8} \mathrm{USD} \mathrm{y}^{-1}$ increase in ESVs from 1990-2015 due to the increase of cropland and forest cover. Zhao et al. [113] assessed the LULC changes and ESVs in the Koshi River Basin (KRB) and found that the latter decreased by $2.05 \times 10^{8} \mathrm{USD}^{-1}$ from 1990-2010 because of the decrease in forest and glacier cover. Even though large knowledge gaps are still present for different regions, the importance of forest land cover is obvious and changes to it directly affect regional ESVs.

With regard to the elasticity in the KSL, a result of 2.33 indicates that that the conversion of $1 \%$ of land area would result in average changes of $2.33 \%$ in ESVs. The region where changes in ESVs had the highest elasticity in relation to LULC changes was KSL-China, where the high elasticity of ESV change in relation to LULC changes was attributable to the concentrations of unused land, wetland, and water bodies, the LULC types with the highest and the lowest ESVs. In KSL-Nepal, deforestation was the main cause of the high elasticity. Forest cover in KSL-Nepal accounted for the largest proportion of this type of land cover in the KSL and decreased by $394.47 \mathrm{~km}^{2}$ during the studied 15-year period. The elasticity in KSL-India was relatively small, mainly due to the small decrease of forest cover. High elasticity indicates that even small LULC changes would have serious effects on ESVs.

\subsection{Uncertainty and Limitations of This Study}

In this study, we failed to accurately extract the built-up areas in the KSL because of the limited resolution of Landsat images and relevant small buildings in the KSL mountain regions. To resolve this problem, we tried adding nighttime light data to improve accuracy for built-up areas. However, this approach only works in regions with night lights, such as Pithoragarh (Figure S4). Therefore, the changes to built-up areas in KSL-Nepal and KSL-India showed a slightly decreasing trend. Even so, LULC and ESV changes were not strongly affected due to the small proportion of built-up areas and their ESVs of zero. Long time-series LULC change monitoring can reveal more details behind these changes. Given the available images, we only studied the LULC changes from 2000-2015, and thus LULC change fluctuations may have been hidden. In this study, we adopted the benefit/value transfer method presented by Song et al. [89], though many critiques of the benefit/value transfer method remain unanswered. Biophysical models might be more helpful for analyzing complex ecological systems and their impacts.

\section{Conclusions}

In this study, we extended an LULC study to the entire KSL and further assessed the changes in ESVs between 2000 and 2015. During the study period, the KSL experienced significant LULC changes: forest and shrub land decreased by $439.82 \mathrm{~km}^{2}$ and $389.61 \mathrm{~km}^{2}$, respectively, whereas grassland and cropland increased by $548.46 \mathrm{~km}^{2}$ and $346.90 \mathrm{~km}^{2}$, respectively. The conversion of forestry areas to cropland was the main cause of cropland expansion. Meanwhile, the conversion of cropland to shrub land indicates that there 
was farmland abandonment in the KSL. The decrease of forestry areas may pose a threat to biodiversity and livelihoods there. During the studied 15-year period, the large core (>500 acre) forest type decreased by $25.36 \%$ and patch forest increased by $34.29 \%$. Severe forest fragmentation was observed in the KSL, mainly distributed in KSL-Nepal, leading to a decrease in ESVs in the KSL. Between 2000 and 2015, the total ESV in the KSL decreased


The decrease of ESV in forestry areas contributed most to the loss of total ESV and also to the high elasticity. This study revealed that even small LULC changes can cause relevant high ESV changes in the KSL.

Supplementary Materials: The following are available online at https:/ /www.mdpi.com/2073-4 45X/10/2/173/s1, Figure S1. Training points in Google Earth high-resolution image and Landsat5/7/8 false color composite image; Figure S2. Image with empty pixels (left) and processed using focal_mean function (right); Table S1. The confusion matrix in 2000; Table S2. The confusion matrix in 2015; Figure S3. The LULC changes along the elevation in KSL from 2000-2015; Figure S4. Built-up areas of Pithoragarh in 2000 and 2015.

Author Contributions: Y.Z. and L.L. (Linshan Liu) designed the study. C.G. and L.L. (Linshan Liu) conceived the research; C.G. studied and wrote the paper and mapped the land cover data and drew the figures; S.L., L.L. (Lanhui Li), B.Z. and B.C. revised the paper and polished the language. Y.Z. revised the paper and contributed to explanation of the results and the discussion. M.K.R. polished the manuscript. All authors have read and agreed to the published version of the manuscript.

Funding: This work was financially supported by the Second Tibetan Plateau Scientific Expedition and Research (Grant No. 2019QZKK0603), the Strategic Priority Research Program of the Chinese Academy of Sciences (Grant No. XDA20040201), and the National Natural Science Foundation of China (Grant No. 41761144081).

Institutional Review Board Statement: Not applicable.

Informed Consent Statement: Not applicable.

Data Availability Statement: Data used in this study will be available upon request from the first author.

Acknowledgments: We would like to express our thanks to anonymous reviewers for their helpful comments on our study. We would also like to express our special thanks to Wei Bo and Gong Dianqing in the Institute of Geographic Sciences and Natural Resources Research, CAS, for their timely help.

Conflicts of Interest: The authors declare no conflicts of interest.

\section{References}

1. Costanza, R.; DArge, R.; DeGroot, R.; Farber, S.; Grasso, M.; Hannon, B.; Limburg, K.; Naeem, S.; ONeill, R.V.; Paruelo, J.; et al. The value of the world's ecosystem services and natural capital. Nature 1997, 387, 253-260. [CrossRef]

2. Carpenter, S.R.; Mooney, H.A.; Agard, J.; Capistrano, D.; Defries, R.S.; Diaz, S.; Dietz, T.; Duraiappah, A.K.; Oteng-Yeboah, A.; Pereira, H.M.; et al. Science for managing ecosystem services: Beyond the Millennium Ecosystem Assessment. Proc. Natl. Acad. Sci. USA 2009, 106, 1305-1312. [CrossRef]

3. Bennett, E.M.; Peterson, G.D.; Gordon, L.J. Understanding relationships among multiple ecosystem services. Ecol. Lett. 2009, 12, 1394-1404. [CrossRef]

4. Li, S.; Zhang, H.; Zhou, X.; Yu, H.; Li, W. Enhancing protected areas for biodiversity and ecosystem services in the Qinghai-Tibet Plateau. Ecosyst. Serv. 2020, 43, 101090. [CrossRef]

5. Millennium Ecosystem Assessment. Ecosystems and Human Well-Being; Synthesis Island Press: Washington, DC, USA, 2005.

6. Randin, C.F.; Ashcroft, M.B.; Bolliger, J.; Cavender-Bares, J.; Coops, N.C.; Dullinger, S.; Dirnböck, T.; Eckert, S.; Ellis, E.; Fernández, N.; et al. Monitoring biodiversity in the Anthropocene using remote sensing in species distribution models. Remote Sens. Environ. 2020, 239, 111626. [CrossRef]

7. Ellis, E.C. Anthropogenic transformation of the terrestrial biosphere. Philos. Trans. R. Soc. A Math. Phys. Eng. Sci. 2011, 369, 1010-1035. [CrossRef]

8. Waters, C.N.; Zalasiewicz, J.; Summerhayes, C.; Barnosky, A.D.; Poirier, C.; Gałuszka, A.; Cearreta, A.; Edgeworth, M.; Ellis, E.C.; Ellis, M. The Anthropocene is functionally and stratigraphically distinct from the Holocene. Science 2016, 351, d2622. [CrossRef]

9. Costanza, R.; De Groot, R.; Sutton, P.; Van der Ploeg, S.; Anderson, S.J.; Kubiszewski, I.; Farber, S.; Turner, R.K. Changes in the global value of ecosystem services. Glob. Environ. Chang. 2014, 26, 152-158. [CrossRef] 
10. Teixeira, Z.; Teixeira, H.; Marques, J.C. Systematic processes of land use/land cover change to identify relevant driving forces: Implications on water quality. Sci. Total Environ. 2014, 470, 1320-1335. [CrossRef] [PubMed]

11. Newbold, T.; Hudson, L.N.; Arnell, A.P.; Contu, S.; De Palma, A.; Ferrier, S.; Hill, S.L.; Hoskins, A.J.; Lysenko, I.; Phillips, H.R. Has land use pushed terrestrial biodiversity beyond the planetary boundary? A global assessment. Science 2016, 353, 288-291. [CrossRef]

12. Maxwell, S.L.; Fuller, R.A.; Brooks, T.M.; Watson, J.E. Biodiversity: The ravages of guns, nets and bulldozers. Nat. News 2016, 536, 143. [CrossRef] [PubMed]

13. Lambin, E.F.; Geist, H.J.; Lepers, E. Dynamics of land-use and land-cover change in tropical regions. Annu. Rev. Environ. Resour. 2003, 28, 205-241. [CrossRef]

14. Zomer, R.J.; Neufeldt, H.; Xu, J.; Ahrends, A.; Bossio, D.; Trabucco, A.; Van Noordwijk, M.; Wang, M. Global Tree Cover and Biomass Carbon on Agricultural Land: The contribution of agroforestry to global and national carbon budgets. Sci. Rep. 2016, 6, 1-12. [CrossRef] [PubMed]

15. Van Asselen, S.; Verburg, P.H. Land cover change or land-use intensification: Simulating land system change with a global-scale land change model. Glob. Chang. Biol. 2013, 19, 3648-3667. [CrossRef] [PubMed]

16. Liu, J.; Liu, M.; Tian, H.; Zhuang, D.; Zhang, Z.; Zhang, W.; Tang, X.; Deng, X. Spatial and temporal patterns of China's cropland during 1990-2000: An analysis based on Landsat TM data. Remote Sens. Environ. 2005, 98, 442-456. [CrossRef]

17. Brooks, T.M.; Mittermeier, R.A.; Da Fonseca, G.A.; Gerlach, J.; Hoffmann, M.; Lamoreux, J.F.; Mittermeier, C.G.; Pilgrim, J.D.; Rodrigues, A.S. Global biodiversity conservation priorities. Science 2006, 313, 58-61. [CrossRef]

18. Kruckeberg, A.R.; Rabinowitz, D. Biological aspects of endemism in higher plants. Annu. Rev. Ecol. Syst. 1985, 16, 447-479. [CrossRef]

19. Locatelli, B.; Lavorel, S.; Sloan, S.; Tappeiner, U.; Geneletti, D. Characteristic trajectories of ecosystem services in mountains. Front. Ecol. Environ. 2017, 15, 150-159. [CrossRef]

20. Wang, Y.; Dai, E.; Yin, L.; Ma, L. Land use/land cover change and the effects on ecosystem services in the Hengduan Mountain region, China. Ecosyst. Serv. 2018, 34, 55-67. [CrossRef]

21. Vigl, L.E.; Schirpke, U.; Tasser, E.; Tappeiner, U. Linking long-term landscape dynamics to the multiple interactions among ecosystem services in the European Alps. Landsc. Ecol. 2016, 31, 1903-1918. [CrossRef]

22. Gurung, J.; Chettri, N.; Sharma, E.; Ning, W.; Chaudhary, R.P.; Badola, H.K.; Wangchuk, S.; Uprety, Y.; Gaira, K.S.; Bidha, N.; et al. Evolution of a transboundary landscape approach in the Hindu Kush Himalaya: Key learnings from the Kangchenjunga Landscape. Glob. Ecol. Conserv. 2019, 17, e599. [CrossRef]

23. Uddin, K.; Chaudhary, S.; Chettri, N.; Kotru, R.; Murthy, M.; Chaudhary, R.P.; Ning, W.; Shrestha, S.M.; Gautam, S.K. The changing land cover and fragmenting forest on the Roof of the World: A case study in Nepal's Kailash Sacred Landscape. Landsc. Urban Plan. 2015, 141, 1-10. [CrossRef]

24. Molden, D.; Sharma, E.; Shrestha, A.B.; Chettri, N.; Pradhan, N.S.; Kotru, R. Advancing Regional and Transboundary Cooperation in the Conflict-Prone Hindu Kush-Himalaya. Mt. Res. Dev. 2017, 37, 502-508. [CrossRef]

25. Mittermeier, R.A.; Turner, W.R.; Larsen, F.W.; Brooks, T.M.; Gascon, C. Global Biodiversity Conservation: The Critical Role of Hotspots; Springer: Berlin, Germany, 2011; pp. 3-22.

26. Uddin, K.; Shrestha, H.L.; Murthy, M.S.R.; Bajracharya, B.; Shrestha, B.; Gilani, H.; Pradhan, S.; Dangol, B. Development of 2010 national land cover database for the Nepal. J. Environ. Manag. 2015, 148, 82-90. [CrossRef] [PubMed]

27. Sharma, E.; Chettri, N. ICIMOD's transboundary biodiversity management initiative in the Hindu Kush-Himalayas. Mt. Res. Dev. 2005, 278-281. [CrossRef]

28. Mackay, A. Climate Change 2007: Impacts, Adaptation and Vulnerability. Contribution of Working Group II to the Fourth Assessment Report of the Intergovernmental Panel on Climate Change. J. Environ. Qual. 2008, 37, 2407. [CrossRef]

29. IPCC. Climate Change 2014: Impacts, Adaptation, and Vulnerability. Part A: Global and Sectoral Aspects. Contribution of Working Group II to the Fifth Assessment Report of the Intergovernmental Panel on Climate Change; Cambridge University Press: Cambridge, UK; New York, NY, USA, 2014; p. 1132.

30. Chettri, N.; Shakya, B.; Thapa, R.; Sharma, E. Status of a protected area system in the Hindu Kush-Himalayas: An analysis of PA coverage. Int. J. Biodivers. Sci. Manag. 2008, 4, 164-178. [CrossRef]

31. Oli, K.P.; Chaudhary, S.; Sharma, U.R. Are governance and management effective within protected areas of the Kanchenjunga landscape (Bhutan, India and Nepal). Parks 2013, 19, 25-36. [CrossRef]

32. Gu, C.; Zhao, P.; Chen, Q.; Li, S.; Li, L.; Liu, L.; Zhang, Y. Forest Cover Change and the Effectiveness of Protected Areas in the Himalaya since 1998. Sustainability 2020, 12, 6123. [CrossRef]

33. De Castro-Pardo, M.; Pérez-Rodríguez, F.; Martín-Martín, J.M.; Azevedo, J.C. Modelling stakeholders' preferences to pinpoint conflicts in the planning of transboundary protected areas. Land Use Policy 2019, 89, 104233. [CrossRef]

34. Sharma, E.; Chettri, N.; Gurung, J.; Shakya, B. The Landscape Approach in Biodiversity Conservation; ICIMOD: Kathmandu, Nepal, 2007.

35. Chettri, N.; Sharma, E.; Thapa, R. Long Term Monitoring Using Transect and Landscape Approaches within Hindu Kush Himalayas; ICIMOD: Kathmandu, Nepal, 2009; pp. 201-208.

36. Zomer, R.J.; Trabucco, A.; Metzger, M.; Oli, K.P. Environmental stratification of Kailash Sacred Landscape and projected climate change impacts on ecosystems and productivity. ICIMOD 2013, 13, 1-25. 
37. Oli, K.P.; Zomer, R. Kailash Sacred Landscape Conservation Initiative: Feasibility Assessment Report; International Centre for Integrated Mountain Development (ICIMOD): Kathmandu, Nepal, 2011.

38. Duan, C.; Shi, P.; Song, M.; Zhang, X.; Zong, N.; Zhou, C. Land Use and Land Cover Change in the Kailash Sacred Landscape of China. Sustainability 2019, 11, 1788. [CrossRef]

39. Singh, G.; Sarkar, M.S.; Pandey, A.; Lingwal, S.; Rai, I.D.; Adhikari, B.S.; Rawat, G.S.; Rawal, R.S. Quantifying Four Decades of Changes in Land Use and Land Cover in India's Kailash Sacred Landscape: Suggested Option for Priority Based Patch Level Future Forest Conservation. J. Indian Soc. Remote 2018, 46, 1625-1635. [CrossRef]

40. Inglada, J.; Vincent, A.; Arias, M.; Tardy, B.; Morin, D.; Rodes, I. Operational high resolution land cover map production at the country scale using satellite image time series. Remote Sens. 2017, 9, 95. [CrossRef]

41. Foley, J.A.; DeFries, R.; Asner, G.P.; Barford, C.; Bonan, G.; Carpenter, S.R.; Chapin, F.S.; Coe, M.T.; Daily, G.C.; Gibbs, H.K. Global consequences of land use. Science 2005, 309, 570-574. [CrossRef]

42. Gorelick, N.; Hancher, M.; Dixon, M.; Ilyushchenko, S.; Thau, D.; Moore, R. Google Earth Engine: Planetary-scale geospatial analysis for everyone. Remote Sens. Environ. 2017, 202, 18-27. [CrossRef]

43. Kumar, L.; Mutanga, O. Google Earth Engine Applications Since Inception: Usage, Trends, and Potential. Remote Sens. 2018, 10, 1509. [CrossRef]

44. Tsai, Y.; Stow, D.; Chen, H.; Lewison, R.; An, L.; Shi, L. Mapping Vegetation and Land Use Types in Fanjingshan National Nature Reserve Using Google Earth Engine. Remote Sens. 2018, 10, 927. [CrossRef]

45. Zhou, B.; Okin, G.S.; Zhang, J. Leveraging Google Earth Engine (GEE) and machine learning algorithms to incorporate in situ measurement from different times for rangelands monitoring. Remote Sens. Environ. 2020, 236, 111521. [CrossRef]

46. Martín-Ortega, P.; García-Montero, L.G.; Sibelet, N. Temporal Patterns in Illumination Conditions and Its Effect on Vegetation Indices Using Landsat on Google Earth Engine. Remote Sens. 2020, 12, 211. [CrossRef]

47. Chakraborty, T.; Lee, X. A simplified urban-extent algorithm to characterize surface urban heat islands on a global scale and examine vegetation control on their spatiotemporal variability. Int. J. Appl. Earth Obs. 2019, 74, 269-280. [CrossRef]

48. Yu, Z.; Yao, Y.; Yang, G.; Wang, X.; Vejre, H. Strong contribution of rapid urbanization and urban agglomeration development to regional thermal environment dynamics and evolution. Forest Ecol. Manag. 2019, 446, 214-225. [CrossRef]

49. Duan, Y.; Li, X.; Zhang, L.; Liu, W.; Liu, S.; Chen, D.; Ji, H. Detecting spatiotemporal changes of large-scale aquaculture ponds regions over 1988-2018 in Jiangsu Province, China using Google Earth Engine. Ocean Coast. Manag. 2020, 188, 105144. [CrossRef]

50. Oliphant, A.J.; Thenkabail, P.S.; Teluguntla, P.; Xiong, J.; Gumma, M.K.; Congalton, R.G.; Yadav, K. Mapping cropland extent of Southeast and Northeast Asia using multi-year time-series Landsat 30-m data using a random forest classifier on the Google Earth Engine Cloud. Int. J. Appl. Earth Obs. 2019, 81, 110-124. [CrossRef]

51. Xie, Z.; Phinn, S.R.; Game, E.T.; Pannell, D.J.; Hobbs, R.J.; Briggs, P.R.; McDonald-Madden, E. Using Landsat observations (1988-2017) and Google Earth Engine to detect vegetation cover changes in rangelands-A first step towards identifying degraded lands for conservation. Remote Sens. Environ. 2019, 232, 111317. [CrossRef]

52. Yao, F.; Wang, J.; Wang, C.; Crétaux, J. Constructing long-term high-frequency time series of global lake and reservoir areas using Landsat imagery. Remote Sens. Environ. 2019, 232, 111210. [CrossRef]

53. Zhou, Y.; Dong, J.; Xiao, X.; Liu, R.; Zou, Z.; Zhao, G.; Ge, Q. Continuous monitoring of lake dynamics on the Mongolian Plateau using all available Landsat imagery and Google Earth Engine. Sci. Total Environ. 2019, 689, 366-380. [CrossRef]

54. Daldegan, G.A.; Roberts, D.A.; Ribeiro, F.D.F. Spectral mixture analysis in Google Earth Engine to model and delineate fire scars over a large extent and a long time-series in a rainforest-savanna transition zone. Remote Sens. Environ. 2019, 232, 111340. [CrossRef]

55. Zhang, Y.; Li, B.; Zheng, D. Datasets of the boundary and area of the Tibetan Plateau. Acta Geogr. Sin. 2014, 69, 164-168.

56. Newman, M.E.; McLaren, K.P.; Wilson, B.S. Assessing deforestation and fragmentation in a tropical moist forest over 68 years; the impact of roads and legal protection in the Cockpit Country, Jamaica. Forest Ecol. Manag. 2014, 315, 138-152. [CrossRef]

57. Xie, F.; Wu, X.; Liu, L.; Zhang, Y.; Paudel, B. Land use and land cover change within the Koshi River Basin of the central Himalayas since 1990. J. Mt. Sci. Engl. 2021, 18, 159-177. [CrossRef]

58. Wu, X.; Gao, J.; Zhang, Y.; Liu, L.; Zhao, Z.; Paudel, B. Land Cover Status in the Koshi River Basin, Central Himalayas. J. Resour. Ecol. 2017, 8, 10-19.

59. Zhang, Y.; Wu, X.; Zheng, D. Vertical differentiation of land cover in the central Himalayas. J. Geogr. Sci. 2020, 30, 969-987. [CrossRef]

60. Campbell, J.B.; Wynne, R.H. Introduction to Remote Sensing; Guilford Press: New York, NY, USA, 2011.

61. De Alban, J.; Connette, G.; Oswald, P.; Webb, E. Combined Landsat and L-Band SAR Data Improves Land Cover Classification and Change Detection in Dynamic Tropical Landscapes. Remote Sens. 2018, 10, 306. [CrossRef]

62. Griffiths, P.; van der Linden, S.; Kuemmerle, T.; Hostert, P. A Pixel-Based Landsat Compositing Algorithm for Large Area Land Cover Mapping. IEEE J. Stars. 2013, 6, 2088-2101. [CrossRef]

63. Hansen, M.C.; Loveland, T.R. A review of large area monitoring of land cover change using Landsat data. Remote Sens. Environ. 2012, 122, 66-74. [CrossRef]

64. Wulder, M.A.; Masek, J.G.; Cohen, W.B.; Loveland, T.R.; Woodcock, C.E. Opening the archive: How free data has enabled the science and monitoring promise of Landsat. Remote Sens. Environ. 2012, 122, 2-10. [CrossRef] 
65. White, J.C.; Wulder, M.A.; Hobart, G.W.; Luther, J.E.; Hermosilla, T.; Griffiths, P.; Coops, N.C.; Hall, R.J.; Hostert, P.; Dyk, A.; et al. Pixel-Based Image Compositing for Large-Area Dense Time Series Applications and Science. Can. J. Remote Sens. 2014, 40, 192-212. [CrossRef]

66. Wilson, B.T.; Knight, J.F.; McRoberts, R.E. Harmonic regression of Landsat time series for modeling attributes from national forest inventory data. ISPRS J. Photogramm. 2018, 137, 29-46. [CrossRef]

67. Huang, H.; Chen, Y.; Clinton, N.; Wang, J.; Wang, X.; Liu, C.; Gong, P.; Yang, J.; Bai, Y.; Zheng, Y.; et al. Mapping major land cover dynamics in Beijing using all Landsat images in Google Earth Engine. Remote Sens. Environ. 2017, 202, 166-176. [CrossRef]

68. Teluguntla, P.; Thenkabail, P.S.; Oliphant, A.; Xiong, J.; Gumma, M.K.; Congalton, R.G.; Yadav, K.; Huete, A. A 30-m landsatderived cropland extent product of Australia and China using random forest machine learning algorithm on Google Earth Engine cloud computing platform. ISPRS J. Photogramm. 2018, 144, 325-340. [CrossRef]

69. Xiong, J.; Thenkabail, P.; Tilton, J.; Gumma, M.; Teluguntla, P.; Oliphant, A.; Congalton, R.; Yadav, K.; Gorelick, N. Nominal 30-m Cropland Extent Map of Continental Africa by Integrating Pixel-Based and Object-Based Algorithms Using Sentinel-2 and Landsat-8 Data on Google Earth Engine. Remote Sens. 2017, 9, 1065. [CrossRef]

70. Tucker, C.J. Red and photographic infrared linear combinations for monitoring vegetation. Remote Sens. Environ. 1978, 8, 127-150. [CrossRef]

71. Fensholt, R.; Sandholt, I. Derivation of a shortwave infrared water stress index from MODIS near-and shortwave infrared data in a semiarid environment. Remote Sens. Environ. 2003, 87, 111-121. [CrossRef]

72. Riggs, G.A.; Hall, D.K.; Salomonson, V.V. A Snow Index for the Landsat Thematic Mapper and Moderate Resolution Imaging Spectroradiometer; IEEE: Piscataway, NJ, USA, 1994; Volume 4, pp. 1942-1944.

73. Xiao, X.; Hagen, S.; Zhang, Q.; Keller, M.; Moore, B., III. Detecting leaf phenology of seasonally moist tropical forests in South America with multi-temporal MODIS images. Remote Sens. Environ. 2006, 103, 465-473. [CrossRef]

74. Van Deventer, A.P.; Ward, A.D.; Gowda, P.H.; Lyon, J.G. Using thematic mapper data to identify contrasting soil plains and tillage practices. Photogramm. Eng. Remote Sens. 1997, 63, 87-93.

75. Goodwin, N.R.; Coops, N.C.; Wulder, M.A.; Gillanders, S.; Schroeder, T.A.; Nelson, T. Estimation of insect infestation dynamics using a temporal sequence of Landsat data. Remote Sens. Environ. 2008, 112, 3680-3689. [CrossRef]

76. Escuin, S.; Navarro, R.; Fernandez, P. Fire severity assessment by using NBR (Normalized Burn Ratio) and NDVI (Normalized Difference Vegetation Index) derived from LANDSAT TM/ETM images. Int. J. Remote Sens. 2008, 29, 1053-1073. [CrossRef]

77. Gitelson, A.A.; Kaufman, Y.J.; Stark, R.; Rundquist, D. Novel algorithms for remote estimation of vegetation fraction. Remote Sens. Environ. 2002, 80, 76-87. [CrossRef]

78. Crist, E.P.; Cicone, R.C. A Physically-Based Transformation of Thematic Mapper Data-The TM Tasseled Cap. IEEE Trans. Geosci. Remote. 1984, GE-22, 256-263. [CrossRef]

79. Pal, M. Random forest classifier for remote sensing classification. Int. J. Remote Sens. 2005, 26, 217-222. [CrossRef]

80. Belgiu, M.; Drăguț, L. Random forest in remote sensing: A review of applications and future directions. ISPRS J. Photogramm. 2016, 114, 24-31. [CrossRef]

81. Congalton, R.G. A review of assessing the accuracy of classifications of remotely sensed data. Remote Sens. Environ. 1991, 37, 35-46. [CrossRef]

82. Andersson, E.; McPhearson, T.; Kremer, P.; Gomez-Baggethun, E.; Haase, D.; Tuvendal, M.; Wurster, D. Scale and context dependence of ecosystem service providing units. Ecosyst. Serv. 2015, 12, 157-164. [CrossRef]

83. Sun, Z.; Xu, R.; Du, W.; Wang, L.; Lu, D. High-resolution urban land mapping in China from sentinel $1 \mathrm{~A} / 2$ imagery based on Google Earth Engine. Remote Sens. 2019, 11, 752. [CrossRef]

84. Kobayashi, T.; Umehara, T.; Satake, M.; Nadai, A.; Uratsuka, S.; Manabe, T.; Masuko, H.; Shimada, M.; Shinohara, H.; Tozuka, H. Airborne dual-frequency polarimetric and interferometric SAR. IEICE Trans. Commun. 2000, 83, $1945-1954$.

85. Reid, R.S.; Kruska, R.L.; Muthui, N.; Taye, A.; Wotton, S.; Wilson, C.J.; Mulatu, W. Land-use and land-cover dynamics in response to changes in climatic, biological and socio-political forces: The case of southwestern Ethiopia. Landsc. Ecol. 2000, 15, 339-355. [CrossRef]

86. Cao, Y.; Zhou, W.; Wang, J.; Yuan, C. Spatial-temporal pattern and differences of land use changes in the Three Gorges Reservoir Area of China during 1975-2005. J. Mt. Sci.-Engl. 2011, 8, 551-563. [CrossRef]

87. Vogt, P.; Riitters, K.H.; Estreguil, C.; Kozak, J.; Wade, T.G.; Wickham, J.D. Mapping spatial patterns with morphological image processing. Landsc. Ecol. 2007, 22, 171-177. [CrossRef]

88. Xie, G.D.; Zhen, L.; Lu, C.X.; Xiao, Y. Expert knowledge based valuation method of ecosystem services in China. J. Nat. Resour. 2008, 23, 911-919.

89. Song, W.; Deng, X. Land-use/land-cover change and ecosystem service provision in China. Sci. Total Environ. 2017, 576, 705-719. [CrossRef]

90. Kanade, R.; John, R. Topographical influence on recent deforestation and degradation in the Sikkim Himalaya in India; Implications for conservation of East Himalayan broadleaf forest. Appl. Geogr. 2018, 92, 85-93. [CrossRef]

91. Munsi, M.; Malaviya, S.; Oinam, G.; Joshi, P.K. A landscape approach for quantifying land-use and land-cover change (1976-2006) in middle Himalaya. Reg. Environ. Chang. 2010, 10, 145-155. [CrossRef]

92. Hofer, T.; Messerli, B. Floods in Bangladesh: History, Dynamics and Rethinking the Role of the Himalayas; UNU Press: Tokyo, Japan; FAO: Roma, Italy, 2006. 
93. Hansen, M.C.; Potapov, P.V.; Moore, R.; Hancher, M.; Turubanova, S.A.; Tyukavina, A.; Thau, D.; Stehman, S.V.; Goetz, S.J.; Loveland, T.R. High-resolution global maps of 21st-century forest cover change. Science 2013, 342, 850-853. [CrossRef]

94. Adnan, A.; QI-Jing, L.; M., N.S.; Abdul, M.; Sajjad, S. Carbon emission from deforestation, forest degradation and wood harvest in the temperate region of Hindukush Himalaya, Pakistan between 1994 and 2016. Land Use Policy 2018, 781-790. [CrossRef]

95. Tambe, S.; Arrawatia, M.L.; Sharma, N. Assessing the priorities for sustainable forest management in the Sikkim Himalaya, India: A remote sensing based approach. J. Indian Soc. Remote 2011, 39, 555-564. [CrossRef]

96. Achard, F.; DeFries, R.; Eva, H.; Hansen, M.; Mayaux, P.; Stibig, H.J. Pan-tropical monitoring of deforestation. Environ. Res. Lett. 2007, 2, 45022. [CrossRef]

97. Sarkar, M.S.; Pandey, A.; Singh, G.; Lingwal, S.; John, R.; Hussain, A.; Rawat, G.S.; Rawal, R.S. Multiscale statistical approach to assess habitat suitability and connectivity of common leopard (Panthera pardus) in Kailash Sacred Landscape, India. Spat. Stat. 2018, 28, 304-318. [CrossRef]

98. Singh, J.S.; Pandey, U.; Tiwari, A.K. Man and forests: A Central Himalayan case study. Ambio 1984, 13, 80-87.

99. Smadja, J. Studies of climatic and human impacts and their relationship on a mountain slope above Salme in the Himalayan Middle Mountains, Nepal. Mt. Res. Dev. 1992, 12, 1-28. [CrossRef]

100. Xu, J.; Grumbine, R.E.; Shrestha, A.; Eriksson, M.; Yang, X.; Wang, Y.; Wilkes, A. The melting Himalayas: Cascading effects of climate change on water, biodiversity, and livelihoods. Conserv. Biol. 2009, 23, 520-530. [CrossRef] [PubMed]

101. Bawa, K.S.; Koh, L.P.; Lee, T.M.; Liu, J.; Ramakrishnan, P.S.; Douglas, W.Y.; Zhang, Y.; Raven, P.H. China, India, and the environment. Science 2010, 327, 1457-1459. [CrossRef]

102. Bertrand, R.; Lenoir, J.; Piedallu, C.; Riofrío-Dillon, G.; de Ruffray, P.; Vidal, C.; Pierrat, J.; Gégout, J. Changes in plant community composition lag behind climate warming in lowland forests. Nature 2011, 479, 517-520. [CrossRef]

103. Thapa, S.; Chitale, V.; Rijal, S.J.; Bisht, N.; Shrestha, B.B. Understanding the dynamics in distribution of invasive alien plant species under predicted climate change in Western Himalaya. PLoS ONE. 2018, 13, e0195752. [CrossRef]

104. Yan, J.; Yang, Z.; Li, Z.; Li, X.; Xin, L.; Sun, L. Drivers of cropland abandonment in mountainous areas: A household decision model on farming scale in Southwest China. Land Use Policy 2016, 57, 459-469. [CrossRef]

105. Paudel, B.; Wu, X.; Zhang, Y.; Rai, R.; Liu, L.; Zhang, B.; Khanal, N.R.; Koirala, H.L.; Nepal, P. Farmland abandonment and its determinants in the different ecological villages of the Koshi River Basin, Central Himalayas: Synergy of high-resolution remote sensing and social surveys. Environ. Res. 2020, 188, 109711. [CrossRef] [PubMed]

106. Jaquet, S.; Schwilch, G.; Hartung-Hofmann, F.; Adhikari, A.; Sudmeier-Rieux, K.; Shrestha, G.; Liniger, H.P.; Kohler, T. Does outmigration lead to land degradation? Labour shortage and land management in a western Nepal watershed. Appl. Geogr. 2015, 62, 157-170. [CrossRef]

107. Paudel, B.; Zhang, Y.; Yan, J.; Rai, R.; Li, L.; Wu, X.; Chapagain, P.S.; Khanal, N.R. Farmers' understanding of climate change in Nepal Himalayas: Important determinants and implications for developing adaptation strategies. Clim. Chang. 2020, 158, 485-502. [CrossRef]

108. Rai, R.; Zhang, Y.; Paudel, B.; Khanal, N. Status of Farmland Abandonment and Its Determinants in the Transboundary Gandaki River Basin. Sustainability 2019, 11, 5267. [CrossRef]

109. Bowen, M.E.; McAlpine, C.A.; House, A.P.; Smith, G.C. Regrowth forests on abandoned agricultural land: A review of their habitat values for recovering forest fauna. Biol. Conserv. 2007, 140, 273-296. [CrossRef]

110. Lambin, E.F.; Turner, B.L.; Geist, H.J.; Agbola, S.B.; Angelsen, A.; Bruce, J.W.; Coomes, O.T.; Dirzo, R.; Fischer, G.; Folke, C. The causes of land-use and land-cover change: Moving beyond the myths. Glob. Environ. Chang. 2001, 11, 261-269. [CrossRef]

111. Shrestha, B.; Ye, Q.; Khadka, N. Assessment of Ecosystem Services Value Based on Land Use and Land Cover Changes in the Transboundary Karnali River Basin, Central Himalayas. Sustainability 2019, 11, 3183. [CrossRef]

112. Rai, R.; Zhang, Y.; Paudel, B.; Acharya, B.K.; Basnet, L. Land use and land cover dynamics and assessing the ecosystem service values in the trans-boundary Gandaki River Basin, Central Himalayas. Sustainability 2018, 10, 3052. [CrossRef]

113. Zhao, Z.; Wu, X.; Zhang, Y.; Gao, J. Assessment of changes in the value of ecosystem services in the Koshi River Basin, Central High Himalayas based on land cover changes and the CA-Markov Model. J. Resour. Ecol. 2017, 8, 67-76. 